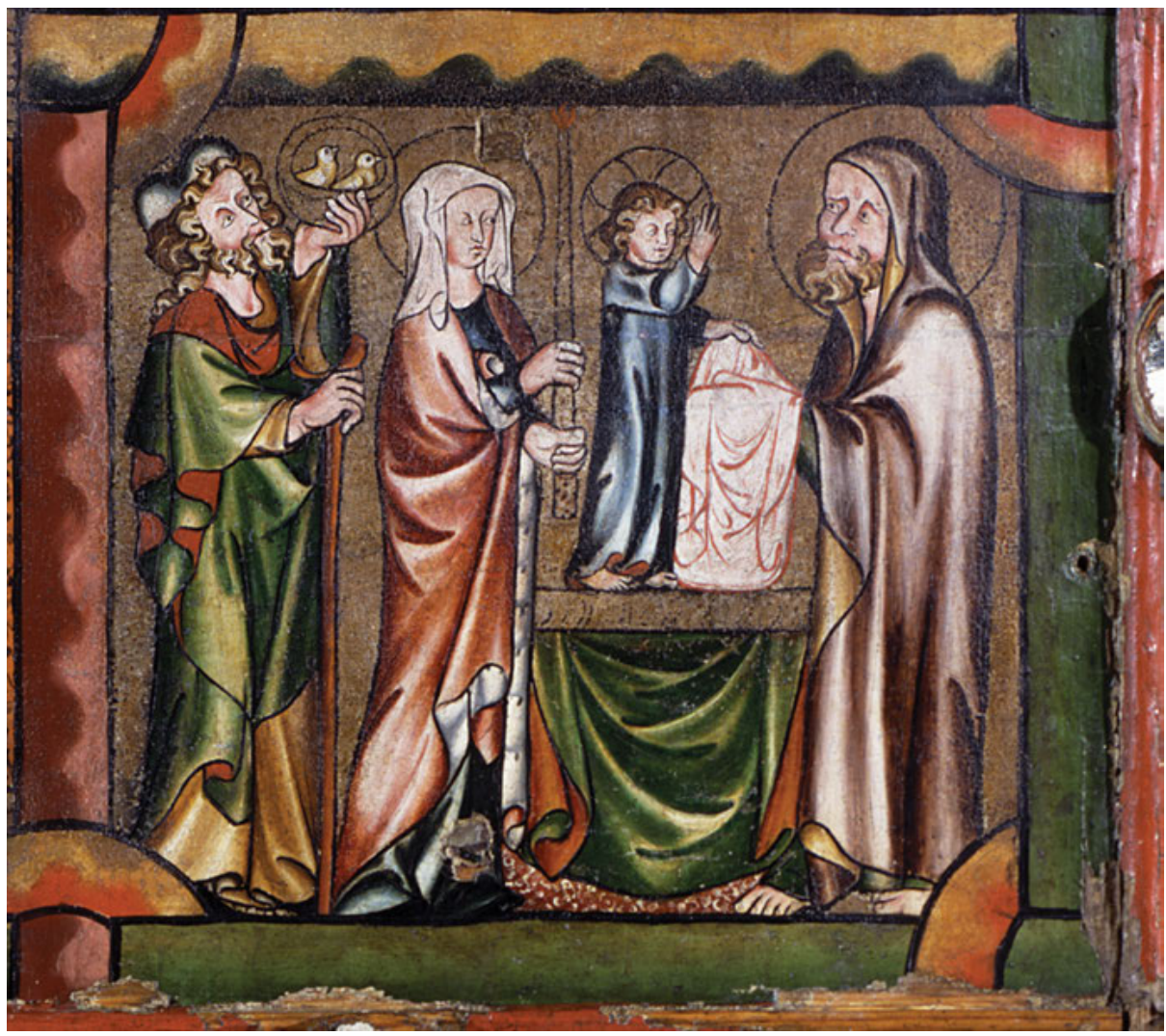

Fig. 17.1: Presentation in the Temple. Detail of the Tresfjord altar panel, c.1325-1350, Tresfjord Church, Møre.

¿ Open Access. (c) 2021 Margrete Syrstad Andås, published by De Gruyter. (c) BY-NC-ND This work is licensed under the Creative Commons Attribution-NonCommercial-NoDerivatives 4.0 International License.

https://doi.org/10.1515/9783110639438-018 


\section{Chapter 17 \\ Entering the Temple of Jerusalem: Candlemas and Churching in the Lives of the Women of the North. A Study of Textual and Visual Sources}

This chapter examines how Candlemas and Churching were celebrated in the North during the medieval period, and how these rituals and the biblical story of the Entry in the Temple of Jerusalem were depicted in the visual arts of the region. Bodily re-enactment, mnemonic objects, words and music constructed an interreferentiality and served to dissolve the distance between the biblical stories and the medieval present. Throughout the cycle of the year, the Temple of Jerusalem was repeatedly brought into peoples' lives, and especially into the lives of women who had become mothers. Acting like Mary established a form of religious kinship between the mother of Christ and the new mother. Bridged by the Churching of her own foremothers, the purification of the medieval woman thus constructed a pseudo-genealogy from Mary to herself. On the threshold of the local church, there simply was no forgetting of Jerusalem.

On the feast of the purification of the Blessed Virgin Mary, when lady Birgitta, the bride of Christ, was in Rome in the church called Santa Maria Maggiore, she was caught up in a spiritual vision and saw how everything in heaven was being made ready as though for a great feast. She saw then, as it were, a temple of wondrous beauty, and there was the venerable and righteous old man, Simeon, ready to receive the child Jesus in his arms with the utmost desire and joy. She also saw the Blessed Virgin approaching most honourably and carrying her little son in order to present him in the temple according to the law of the Lord. Then she saw a countless multitude of angels and the various ranks of God's saints and holy virgins and ladies walking before the Blessed Virgin Mother of God and surrounding her with all gladness and devotion. Ahead of her an angel was carrying a long sword, very broad and bloody, symbolizing the great sorrows that had befallen Mary on the death of her beloved son. These were prefigured by the sword that the righteous Simeon had foretold would pierce her soul. Hence,

Note: The author is grateful to Mette Maria Ahlefeldt-Laurvig for generously sharing sources and texts concerning the Danish material, to Professor Lasse Hodne for insightful comments on the iconography, and to Elisabeth Andersen for bringing a number of depictions of the Presentation in the imagery of medieval Scandinavia to her attention.

Margrete Syrstad Andås, Postdoctoral Fellow, Medieval Art History, NTNU Norwegian University of Science and Technology, Trondheim, Norway 
while the heavenly court exulted, it was said to the bride: "Behold how much honour and glory are rendered on this fest to the Queen of heaven in return for the sword of sorrows which she endured at the passion of her beloved son.” The vision then disappeared. ${ }^{1}$

The revelation of St Birgitta (c.1303-1373) describes the Feast of the Purification of the Blessed Virgin Mary, also called Candlemas, which commemorates three central religious events of entry: (1) the offering of "a male opening the womb" to the temple of Jerusalem, (2) Mary's post-partum re-entry into the Temple of Jerusalem, and (3) the reception of the Christ child by Simeon; the old man who had received a promise from God that he should not see death before he had seen Christ the Lord. All these aspects of Luke 2:22-38 are noted in St Birgitta's vision, yet her revelation contains additional layers of meaning and information less obvious to the modern reader. St Birgitta goes on to describe a procession of virgins and ladies accompanying the blessed Virgin for her entry in the Temple. For a woman like St Birgitta, belonging to the higher stratum of society, and herself many times a mother, the description presumably also reflects her own Churchings, and the Churchings of other women of her standing. There might not have been angels present, but all the best women of her milieu would have been chosen to accompany her as she entered her own church, the local Temple of Jerusalem, and the earthly gate to the heavenly city. ${ }^{2}$ Admittedly, Candlemas was only celebrated once a year, but Churching would have been amongst the more frequently celebrated of medieval rituals, following the birth of a child, whether this lived or died. And every time, the earthly and the heavenly Jerusalem were brought into play through the repetition and re-enactment of religious memories, an in the construction of personal ones.

The identification between the local church and the temple of Jerusalem was well established in medieval religiosity. From the twelfth to the fifteenth century, homilies for the Dedication fest are preserved from the Nidaros province that explains how the temple of Solomon was a model for the medieval church building, and some recall Solomon's prayer to God wherein God reveals his presence in the temple. $^{3}$ In liturgical prescriptive texts, the church is often referred to as the temple. The Ordo Nidrosiense, the ordinal for the Nidaros province with prescriptions for the cyclical fests, prescribes how certain outdoor processions shall continue until

1 Birgitta of Sweden, The Revelations of St. Birgitta of Sweden, 4 vols, trans. Denis Searby, Oxford: Oxford University Press, 2006-2015. book VI, ch. 2, 206-07 I am grateful to Maria Husabø Oen for bringing this passage to my attention. For St Birgitta and Jerusalem, see Chapter 13 (Maria H. Oen), 245-67.

2 On this, see also the Introduction, 35-6, and Chapter 15 (Line M. Bonde), 299-323.

3 For Cod. AM. $6194^{\circ}$, see Gammelnorsk homiliebok, trans. Astrid Salvesen with an introduction by Erik Gunnes, (Oslo: Universitetsforlaget, 1971), 12, 95-100, and 176. The basic structure of the "In dedicatione tempeli sermo" points back to Origines' homily of the tabernacle. Another compilation of homiletic texts is published under the heading Messuskýringar. In this context ch. VII is relevant, Messuskýringar, trans. Elise Kleivane, ed. Sigurd Hareide, et al. (Oslo: St. Olav forlag, 2014), 85-6. 
the door of the temple. ${ }^{4}$ Also in the priestly handbooks, the church is described as the temple. In the marriage rituals of the Manuale Norwegicum, dating from the twelfth to the fourteenth century, the rings shall be blessed "ante hostium temple," before the door of the temple. ${ }^{5}$ The baptismal texts, on the other hand, applies the term ecclesia for what shall be done, whereas the text that the priest is to read out says Jngredere in templum dei, enter God's temple. ${ }^{6}$ Applying ecclesia for descriptive purposes was not uncommon. This may for instance also be observed in the only pontifical fragment thought to actually have belonged to the archiepiscopal cathedral of Nidaros. ${ }^{7}$

In her discussion of the physical church as the Heavenly Jerusalem, Ann R. Meyer demonstrates how the liturgy identifies the building as "the location for a possibility of passage between the temporal and sacred realms." 8 She observes the same thing as we see in the texts form the North; the church is both the church building of the present, the Temple of Jerusalem, and the eternal Temple of God; the Jerusalem above. The "here and now" and the "there and then" are at the same time both separate and the same. It is acknowledged in words that to enter into the church is also to enter the eternal temple of God.

At the moment of entry, Candlemas brings Jerusalem and its temple into play; the door of the church, the door of the temple of Solomon, and the door of the temple of God melts together. ${ }^{9}$ Through constant repetition, the act of entry in itself evokes these associations. To understand these processes, a brief glance to the field of memory studies may be helpful.

4 In capite ieiunii: “. . . cantando antiphonas processionales usque ad ostium temple;” Dominica in octavis pasche: "Que si non suffecerint, cantetur Salue festa dies usque ad ostium templi et ibi finiatur. Ad introitum templi antiphona Sedit angelus imponatur vel Rex noster et fiat statio ante crucem.," Dominica prima post trinitatem: “Que si non suffecerit, addatur antiphona Cum uenerimus et ante hostium templi finiatur.” Ordo Nidrosiensis ecclesiae, ed. Lilli Gjerløw, Libri liturgici provinciae Nidrosiensis medii aevi, 2 (Oslo: Norsk Historisk Kjeldeskrift-Institutt, 1968), 200, 243, 268-9

5 Manuale Norwegicum, ed. H. Fæhn, Libri liturgici Provinciae Nidrosiensis Medii Aevi, I (Oslo: Norsk Historisk Kjeldeskrift-institutt, 1962), 19, 85-5, 152-3.

6 Manuale Norwegicum 152-3.

7 The fragments contain parts of the dedication ritual, and parts of the prescriptions for the reconciliation of a church. From the dedication, we recognise the ritual element where the church is to be marked in twelve places with crismat; "cum crismat ecclesiam signare in duodecim locis," and throughout the consecration prescriptions, the church is repeatedly referred to as ecclesia, NRA lat. fragm.1054-1059 (unpublished).

8 "The liturgy itself identifies the building as the habitation of God; the location for a possibility of passage between the temporal and the sacred realms; a confirmation and celebration of the events of Christ's life; a reminder and preparation of the Last judgment; and finally, a community of worshippers, whose individual members are the true temples, the living stones, the sacramental signa of the Church," Ann R. Meyer, Medieval Allegory and the Building of the New Jerusalem (Cambridge: D. S. Brewer, 2003), 94. See also her "Introduction."

9 Cf. Chapter 15 (Line M. Bonde), 299-301, including Fig. 15.1. 


\section{Communicative Memory, Communal Memory, and the Floating Gap}

Maurice Halbwachs (1877-1945) demonstrated how memory depends on socialization and communication, and how it may thus be analysed as a function of our social life and our belonging to social groups. Halbwachs' term "collective memory" has since then been much used. ${ }^{10}$ Jan Assmann is one of those who have further developed his ideas. Assmann's writing sheds light upon the use of models in the development and construction of memory and identity, and his perspective may be productive in the analysis of the role of the theological motif of the Entry in the Temple as a model for the medieval worshiper.

Memory enables us to form an awareness of identity, both on the personal and on the collective level. ${ }^{11}$ Assmann suggests that it would be helpful to separate not only between the inner neuro mental level and the social level, but also between the social and the cultural level. The latter two categories construct a productive framework in the distinction between Churching and Candlemas.

Assmann's term "cultural memory" describes memories that may be placed in historical, mythical and cultural time; memories that are based on fixed points in the past, and concerns cultural identity. Such memories are not about the past as it was, but the past as it is remembered:

[. . .] the past is not preserved as such, but is cast in symbols as they are represented in oral myths or in writings, performed in fests, and as they are continually illuminating a changing present. In the context of cultural memory, the distinction between myth and history vanishes. ${ }^{12}$

Candlemas typically falls into the category of "cultural memory;" it concerns the distant past, which through commemoration is established in the individual worshiper's memory, it has a high degree of formation and ceremonial communication, it is mediated in texts and performed ritual, and it is led by specialized carriers of memory in a hierarchical structure. ${ }^{13}$

Churching falls into the category of "communicative memory." Communicative memory concerns that which is non-institutional, communicative, and developed in social time, as a carrier of social roles. Assmann associates communicative memory

10 Maurice Halbwachs, On Collective Memory, ed. and trans. Lewis A. Coser (Chicago: The University of Chicago Press, 1992). Originally published in Félix Alcan, ed. Collection: Les travaux de l'Année sociologique (Paris: Les Presses universitaires de France, 1925).

11 Jan Assmann, “Communicative and Cultural Memory," in Cultural Memory Studies. An International and Interdiciplinary Handbook, ed. Astrid Eril and Ansgar Nünning (Berlin - New York: W. de Gruyter, 2008), 109-18.

12 Assmann, "Communicative and Cultural Memory," 113.

13 Assmann, "Communicative and Cultural Memory," 117. 
with the time structure of living memory. The participation structure is diffused. Its form is the informal tradition, and autobiographical memory. In the Scandinavian material prescriptions for this ritual are missing, even though it was certainly celebrated. Compared to the rituals of the annual cycle, or the Sacraments, Churching was of a very different nature in the sense that it was voluntary; the woman could choose - at least in theory - to have, or not have, this honourable ceremony of introduction. The memory of Churching would have belonged to the individual woman and her group (family, local community), and its memory would not have lasted longer than living memory. It was located and played out in "real" time, that is in social time, and related to the woman's own social roles. Assmann's communicative memory encompass memories, which are located in the recent past, in our case, memories, which concerns either the woman herself, her mother, grandmother or great grandmother.

Assmann points out how "groups, which, of course, do not "have" a memory tend to "make" themselves one by means of things meant as a reminder."14 Memory consists only in relation to other human memories and "things," and Assmann thus speaks of "the remembering mind" and "the reminding object." In the present context, the church door constitutes such a locus of memory. The door is the physical element used in these rituals, and accordingly, a cluster of associations and memories may be revived there. The rituals fill the space of the door with religious histories. The church door may not be the actual door of the temple of Jerusalem, but it is framed as such in liturgical rituals, and through their actions, the worshipers submit to this idea, and reinforce and renew this mimesis of the temple door. Similarly, the candles are "mnemonic objects," they are invested with memories and are made to play the role of the Christ child, they are held by the worshipper and carried across the threshold.

The informal generational memory refers to the recent past, whereas the formal, the cultural memory, refers to the remote past. The distance between the two events, the Purification of Mary in the temple of Jerusalem and the purification of any medieval mother in her own local church, is bridged by what in Jan Vansina's term would be called "the floating gap." 15 Vansina's observations primarily concerns oral societies, yet he argues that even in literary societies, living memory goes no further back than eighty years. Historical consciousness thus operates on two levels; the times of origins and the recent past. In this particular study, cultural memory and social memory is not only bridged by mnemonic elements such as candles and church doors, but also by the social memory of the foremothers of the new mother. Through these two rituals constant and continuant inter-referentiality, the idea of lineage is established: Acting like Mary constructs a form of religious kinship between Mary and the new mother. Mary is the root of the Christian lineage. The medieval woman's Churching brought

14 Assmann, “Communicative and Cultural Memory," 111.

15 Assmann, "Communicative and Cultural Memory," 112-3, referring to Jan Vansina, Oral Tradition as History (Madison: Univ. of Wisconsin Press, 1985). 
her into a long line of devout and honourable women; by the ritual acts of her own foremothers a pseudo-genealogy to Mary is established.

\section{The Celebration of Candlemas and the Motif of the Presentation in the Visual Art of the North}

Before we move on to consider the visual art and the ritual practices, we should for a moment look at the biblical story, as if looking at the script of a play with a scene, artefacts, and characters entering. In the Vulgate (Luke 2:24-38) we hear that they (Mary and Joseph) brought him (Jesus) to Jerusalem. As sacrifice they brought $a$ pair of turtledoves or two young pigeons. There was a man in Jerusalem named Simeon. He was already waiting in the temple, because he had received a promise from the Holy Ghost that he should not see death until he had seen Christ the Lord. When his parents brought in the Child Jesus, Simeon took him in his arms and blessed God, and proclaimed his prophecy, where he saw the sword that would pierce Mary's soul. At the same hour, also Anna came in. Anna was "far advanced in years," since long a widow, and lived her life in fasting and prayer. Anna also spoke of him to all who looked for the redemption of Israel. The Gospel of Pseudo-Matthew (chapter 15) does not diverge much from this, it gives Anna the line "In Him is the redemption of the world," and it adds that Simeon, when Jesus was brought forth to him "took Him up into his cloak and kissed His feet."16

By the time the feast of Candlemas reached Scandinavia, the central ceremonial aspects of the celebration were already codified. The meeting between Christ and Simeon was the focal point of the earliest known Candlemas celebration called the Hypapante, the meeting, which is described by the late fourth-century pilgrim Egeria in her accounts from her visit to the Holy Land $c .400{ }^{17}$ The feast was then celebrated with stational liturgy and a procession through the townscape of Jerusalem. Before long, the feast reached Rome, and in the sixth century it was also adopted in the Byzantine Empire. The date of the feast was changed from 14. February to 2. February, so that it would follow forty days after The Feast of the Nativity. ${ }^{18}$ It was then established as a

16 The Gospel of Pseudo-Matthew was well-known throughout the Middle Ages, as this was amongst the «infancy gospels» that attempted to fill out the details of the life of Christ up until the age of 12 . In the later Middle ages, the narrative from Pseudo-Matthew was included in the Legenda Aurea. See The Gospel of Pseudo-Matthew, ed. Alexander Roberts, et al., Ante-Nicene Fathers: The Twelve Patriarchs, Excerpts and Epistles, The Clementina, Apocrypha, Decretals, Memoirs of Edessa and Syriac Documents, Remains of the First Ages, VIII (New York: Christian Literature Publishing Co., 1886) 368-83.

17 John Wilkinson, Egeria's Travels to the Holy Land (Warnminster: Aris \& Phillips, 1982), 128.

18 Dorothy Shorr, "The Iconographic Development of the Presentation in the Temple," The Art Bulletin 28 (1946): 17. 
Marian feast. In liturgical manuscripts it is therefore labelled In purificatione beate marie, or something similar, and it is not part of the temporale, which otherwise would be the place for the liturgical commemoration of events in the life of Christ. In nonliturgical sources, the feast is often labelled Missa candelarum; Candlemas. Comparative continental examples show that Candlemas varied in length and organization; but often the procession went outside to carry the "Christ Child" around the local landscape and to stage the entry in the temple. The procession was an important part of the celebration also when the feast went north, even though it did not always go out of church, but rather it utilized the full length of the interior. The Venerable Bede, writing in the eighth century, describes how clergy and laity went through the churches singing hymns and carrying candles. ${ }^{19}$ In Anglo-Saxon times, the Candlemas procession often went to a station church, like it did in Jerusalem, but the climax of the day was the procession's return to its home church, and the moment of entry. ${ }^{20}$

No processionals are preserved from medieval Scandinavia. Our knowledge of the Candlemas celebration, with the ritual staging of the entry in the temple and the re-enactment played out by the laity, comes from ordinals, breviaries, missals or other liturgical prescriptions or commentaries. ${ }^{21}$ The earliest text giving the full order of the day is the Nidaros ordinal. We first hear of an ordinal serving as a model text for the liturgical life of this province, which covered mainland Norway and the North Sea islands down to Scotland, in 1308, but the core of the text might be a century older. ${ }^{22}$ In the following, I shall take this text as my point of departure.

In purificatione beate marie in the Ordo Nidrosiense explicitly refers to all the religious points of entry mentioned above. ${ }^{23}$ The ritual movements and actions, and the chants throughout the day, explain, interpret and elaborate on Luke 2:22-38. ${ }^{24}$ This is typical. Also from other parts of Scandinavia, prescriptions for the order of the day are fully or partly preserved. From medieval Sweden, the Ordinarius Lincopensis, the ordinal from Lindköping, exists in two copies. Both are from Vadstena, of monastic origin and accordingly, they pay no attention to the laity. Nevertheless, they tell us quite a bit about the order for the Candlemas celebration in the diocese of Linköping in the late

19 Shorr, "The Iconographic Development of the Presentation in the Temple," 18.

20 M. Bradford Bedingfield, The dramatic liturgy of Anglo Saxon England (Woodbridge: Boydel Press, 2002), 54.

21 Alf Härdelin, Världen som yta och fönster. Spiritualitet $i$ medeltidens Sverige, Scripta minora (Stockholm: Selskapet Runica et Mediævalia, 2005), 150, n.46; Hilding Johansson, "Bidrag til den svenska maualetraditionen,” in Lunds universitets årsskrift, N.F Avd. 1. Bd 47. Nr. 6 (Lund: C.W.K. Gleerup, 1951), 65-78.

22 The text has been dated to the late twelfth century by Lilly Gjerløw, whereas recent work by Astrid Marner places the edition as we have it in the late thirteenth century. Ordo Nidrosiensis ecclesiae, 29-30, 34-8, 72; Astrid Marner, Liturgical Change and Liturgical Plurality in the Province of Nidaros. New light on the Odro Nidrosiensis Ecclesiae ([Forthcoming]).

23 Ordo Nidrosiensis ecclesiae, 314.

24 Ordo Nidrosiensis ecclesiae, 312-5. 
fourteenth century. ${ }^{25}$ Under the rubric In festo purificacionis sancte Marie virginis, we find much the same antiphons and responsories as in the Ordo Nidrosiense. These are standard Candlemas hymns quoting or elaborating upon the text from Luke. From Danish Lund is also much preserved, and from Skara, the formula for Mass is preserved both in a missal fragment and in the breviary. ${ }^{26}$ In Skara, the Purificatio beate Marie has the highest grade. The importance of the feast is also mirrored in Rituale Aboensis, from now Finish Åbo, where the octave (February 9) was labelled festum Simeonis. ${ }^{27}$

An important ritual element of this day was the blessing of the candles. ${ }^{28}$ This took place before the procession. For their purification the candles were stenched with blessed water and incensed. The worshipers all held on to their candles throughout the procession, until the offertorium, the section of Mass when bread and wined are placed upon the altar, when the candles were extinguished, and the best of them offered. Manuale Norwegicum contains two prayers for this ritual, and late medieval formula are also preserved from the Swedish dioceses of Skara, Strängnäs, Uppsala, and now Finnish Åbo, as well then Danish Lund, and the Danish Notmark manual from the diocese of Odense. ${ }^{29}$ Also here the texts interpret the narrative from Luke. ${ }^{30}$ This is commonly found, and both the Presentation in the temple and the Meeting are often mentioned especially. In text and performance, layers of symbolism were ascribed to the candle. The candle played the role of Christ as saviour, "the light to the revelation of the gentiles," but it was also the sacrificial lamb; the people's offering. Essentially, the story of Christ was played out through the use of the candles in the short span of the celebration; from the entry in the church where the people re-enacted Simeon and recognized the Messiah, to the end of the celebration when they indeed sacrificed him. The prayer from Lund expands upon the theological paradoxes:

One God, given life by God, yet born by Mary, the one who is both before time and within time, both the dissolution of darkness and the light of faith, who drives away the darkness and sheds light upon the world, both physical external light, and spiritual internal light. ${ }^{31}$

25 The first manuscript is date just before 1400, whereas the latter is dated c.1450. Sven Helander's edition is primarily based on the earliest of the two, Sven Helander, Ordinarius Lincopensis ca 1400 och dess liturgiske förebilder, vol. 4, Bibliotheca Theologiae Practicae (Lund: Gleerup, 1957), 25, 407-24.

26 Hilding Johansson, Den medeltida liturgien i Skara stift- Studier i mässa och helgonkult, Studia theologica lundesia. Skrifter utgivna av teologiska fakulteten i Lund (Lund: C.W.K. Gleerup, 1956), 36.

27 Johansson, Den medeltida liturgien i Skara stift- Studier i mässa och helgonkult, 36.

28 Translation by author based on Härdelin, Världen som yta och fönster, 288-9.

29 Manuale Norwegicum, 176, 79; Hemsjömanualet. En liturgi-historisk studie, ed. Hilding Johansson, Samlingar och studier till svenska kyrkans historia, 24 (Stockholm: Svenska kyrkans diakonistyrelses bokförlag) 1950; Johansson, "Bidrag til den svenska maualetraditionen," 65-70; The Manual from Notmark: Gl. kgl. Saml. 3453, $8^{\circ}$, ed. Ottosen, Bibliotheca Liturgica Danica, Series Latina 1 (Copenhagen: Gad, 1970) Härdelin, Världen som yta och fönster, 288-9.

30 Johansson, "Bidrag til den svenska maualetraditionen," 183-4.

31 Translation by author based on Härdelin, Världen som yta och fönster, 288-9. 
The burning candles should thus symbolize the salvation of the human soul. ${ }^{32}$

In the Nidaros Ordinal it is specified that the custodian shall distribute the burning candles to the clergy and the laity while they sing about Simeon's reception of the Messiah and the greeting of the Virgin. The phrasing may differ, continental texts may for instance prescribe that "each person" shall receive a candle, yet, the point is clear: all shall carry the light of Christ. ${ }^{33}$ The antiphon Lumen ad reuelationem gentium, "the light to the revelation of the gentiles" (Luke 2: 32) is then to be sung after the candles are distributed, or when the candles are lit. The prescriptions in the Missale Scarense are here very similar to Nidaros. ${ }^{34}$ However, not all churches were large and prominent. In small places like Hemsjö, an annex church to the somewhat larger Aligsås where the vicar lived, no procession was held, but the people were still given candles to hold during Mass, thus keeping the ritual re-enactment element, making the congregation not only hear with their ears what the day was about, but also acknowledge it bodily and see the light with their eyes, just like Simeon. ${ }^{35}$

After the blessing and distribution of the candles followed the procession. Margot Fassler's discussion of the Candlemas procession from Chartres reveals that this was not very different from what is prescribed in the Nidaros ordinal. Chartres is however interesting as the procession makes a station before the Royal Portal prior to its re-entry. ${ }^{36}$ The lintel of the Royal Portal features a depiction of the Presentation. ${ }^{37}$ In Chartres, there is thus a certain correspondence between image and bodily re-enactment. From Scandinavia, no examples of this motif similarly placed in an architectural context are preserved.

According to the prescriptions of the Ordo Nidrosiense, the procession exits and walks around the atrium, while they sing processional antiphons typical for Candlemas. ${ }^{38}$ In the Uppsala missals the Purficatio beate Maria is mentioned as a day

32 Härdelin, Världen som yta och fönster, 288-289; Hemsjömanualet, 106-11.

33 Quoting Gittos' translation of Robert of Jumièges, Helen Gittos, Liturgy, Architecture, and Sacred Places in Anglo-Saxon England (Oxford: Oxford University Press, 2013), 120.

34 Ann-Marie Nilsson, "Chants and Provenance of the Fragmentary 12th-century Missal of Skara, Sweden," in Cantus Planus. Papers read at the 12th meeting of the ISM Study Group Lillafüred, Hugary, 2004, Aug. 23-24 (Budapest: Dobszay, László, 2006), 471-8.

35 Hemsjömanualet, 109-110; Härdelin, Världen som yta och fönster, 151 n.48.

36 Margot E. Fassler, “Adventus at Chartres. Ritual Models for Major Processions,” in Ceremonial Culture in PreModern Europe, ed. Nicholas Howe (Notre Dame IN: University of Notre-Dame Press, 2007), 24-7, 57 n.51.

37 On the Marian iconography and liturgy at Chartres, see Margot E. Fassler, "Liturgy and Sacred History in the Twelfth-Century Tympana at Chartres,” The Art Bulletin 75 (1993): 499-520.

38 Ordo Nidrosiensis ecclesiae, 314. The particular reference to a procession in the atrium, also found in the prescriptions for a couple of other feast in the same ordinal, might either be a relic of a model text, reflecting the local situation of the Nidaros cathedral which in its earliest times would have had a large west tower providing apt space for processional activity, or it may reflect the particular situation of Icelandic Skálhot where the preserved texts are from. Skálholt did have an ante structure, a steeple, in the thirteenth- and fourteenth centuries. 
when a procession shall be held. ${ }^{39}$ Little is however know about the route of the procession, but the general rule of the Uppsala Missal was that all the detempore processions should go around the church, "per circuitum ecclesie," presumably then through the church yard. ${ }^{40}$ This is also the case with the Strägnäs missal. ${ }^{41}$ In Lund, a station is even prescribed before the re-entry of the cathedral, while they sing the antiphon "Responsum accepit" (Luke 2:26) which announces the answer Simeon received from God confirming that the child was the Messiah. ${ }^{42}$

Although processions into the townscape are rarely prescribed, outdoor processions were commonly performed on this day, effectively creating correspondence between the processional use of space, and the mnemonic use of the biblical narrative at the point of entry. ${ }^{43}$ Olaus Magnus (1490-1557), a Swedish Catholic priest who writes about the customs of the people of the North at the time of the Lutheran Reformation, notes that on this day, blessed vax candles were carried through the churches and the churchyards in pious prayer and humility. ${ }^{44} \mathrm{He}$ describes this as an old rite that is still kept in high regard because it celebrates "the light to the revelation of the gentiles." Notably, in these northern regions near the Arctic Circle the beginning of the month of February would not see much day light, and the symbolism of the feast must be assumed to have been particularly obvious.

At the moment of entry both the Ordo Nidrosiense, and the fifteenth-century Ordinarius Lincopensis, prescribe "Cum inducerent puerum;"

And when his parents brought in the child Jesus, to do for him according to the custom of the law, he [Simeon] also took him into his arms and blessed God and said Now thou dost dismiss thy servant, O Lord, according to thy word in peace: because my eyes have seen thy salvation.

(Luke 2:27-29)

This antiphon was commonly prescribed in connection with the entry in the church on Candlemas. Thereafter, Mass was celebrated. According to Lund, a sermon should then be read ad pulpito, from the pulpit. ${ }^{45}$ The reference to the pulpit is unusual, but otherwise this follows the norm. The sermons were held in the vernacular, and expanded upon the narrative of Luke. Two virtually identical sermons for

39 Johansson, "Bidrag til den svenska maualetraditionen,” 69.

40 Johansson, "Bidrag til den svenska maualetraditionen,” 69.

41 Johansson, "Bidrag til den svenska maualetraditionen,” 69-70.

42 Johansson, "Bidrag til den svenska maualetraditionen," 70. The other hymns prescribed in the Swedish sources for the Candlemas procession are "Ave gratia plena, dei gentrix," and "Adorna thalamum." Gittos mentions the chants to be sung at the point of entry listed in the Regularis Concordia, which also includes "Responsum accepit," Gittos, Liturgy, Architecture, and Sacred Places, 121.

43 Gittos, Liturgy, Architecture, and Sacred Places, 121, Bedingfield, The dramatic liturgy of Anglo Saxon England, 59.

44 XVI: 6-7, Olaus Magnus. Description of the northern People, Rome 1555, trans. Peter Fischer and Humphrey Higgens, ed. Peter Foote, Hakluyt Society, Second Series, I (New York: Routledge, 1998). 45 Johansson, "Bidrag til den svenska maualetraditionen," 70. 
this feast survive from the Nidaros province. ${ }^{46}$ These are mainly based on Bede and Ambrosius Audbertus, and explicitly points out how Jesus was carried into the temple to be held by Simeon. ${ }^{47}$ The biblical theme of those who cannot see or hear, even though the truth has been revealed before them, is contrasted with the just and devoted Simeon, who saw the Messiah. The vernacular sermons quote Matthew "So let your light shine before men, that they may see your good works, and glorify your Father who is in heaven" (Matt. 5:16). Also the homilies speak about "the light to the revelation of the gentiles," as noted above a biblical quote and one of the most commonly found Candlemas chants. ${ }^{48}$ The sermons then explain the presence of Anna the prophetess; for Christ was sent to save both men and women, and therefore both Simeon and Anna received him in the temple. ${ }^{49}$ The homilies also bring in other themes commonly found in continental texts, and points to Mary as a model of humility and piousness. ${ }^{50}$ These homiletic topics should be kept in mind when the imagery is later examined, for this is what the men and women heard in their local temples in the darkness of February while they held on to their own candles.

At the offertorium of the Mass, when bread and wine were placed upon the altar, the candles were extinguished, and with much ceremony presented as the offering. Olaus Magnus describes that when the procession had gone through the churches and the cemeteries, the blessed candles were placed upon the altar, chopped into pieces, and then distributed to the families after Mass. ${ }^{51}$ Also other sources confirm that each household were allowed to keep one, or rather pieces of, the blessed candles from the Candlemas procession. ${ }^{52}$

The ritual thus ends in quite a powerful way. Through the course of the celebration the salvation history is played out. First the people, clergy and laity alike, greet their Messiah; they carry him like his mother did, and they recognize him as the true Messiah, like Simeon and Anna did. But at the end of the ceremony, at Mass, the lights are offered upon the altar like the sacrificial lamb.

46 Gammelnorsk Homiliebok, 66, 171.

47 Gammelnorsk Homiliebok, 66-9. For a discussion of the textual models, see Gammelnorsk Homiliebok, 170-1.

48 Matt. 5:16; Gammelnorsk Homiliebok, 66-9.

49 Ordo Nidrosiensis ecclesiae, 315. When the candles are distributed, the ordinal only refers to populum, the people, but after the procession, it is explained in great detail that the clergy and the laity go into the chancel to extinguish the candles in water, and the procession ends.

50 Gammelnorsk Homiliebok, 169-70.

51 He then goes on to tell that on the following day the children appear at church, fasting. They kneel with their candles lit, and their father blesses them (Numbers 6). Every child is blessed. Then their hair is arranged in a cross, and the candle extinguished. If the smoke rises to the skies, like the just Able, then this is a good sign, but if it sinks to the floor, then it is a bad sign, and the child must look out for bad influences, XVI: 6-7, Olaus , III, 777.

52 This candle might for instance be lit during the performance of the last rites, and it was considered powerful against foul weather, illness and accidents. In medical texts the same candle is suggested used to heal wounds, Johansson, "Bidrag til den svenska maualetraditionen," 68. 
The motif of the Presentation in the Temple is common in the arts of medieval Scandinavia, and it must be viewed in light of the Candlemas celebration. The culmination of the ceremony, with the offering of the candles upon the altar helps explain a variety of iconographical elements found in the visual depictions, but it also serves as means to understand the significance of the ever-present altar in the depictions of this motif. The altar does not play a part in the biblical script, which only tells us that Simeon was waiting in the temple, still, it becomes something of a fixture in the visual conventions, and figures as a "shorthand" both for the temple of Jerusalem, and as demonstrated above, for the Passion of Christ.

In the North, the motif of the Presentation is mostly preserved on baptismal fonts, in altar panels, in Marian tabernacles, stained glass and murals. How the many versions of the motif reached the North, before the fifteenth- and sixteenth century's large scale import of retables from Germany and the Low Countries, may not be discussed here, but it should be remembered that it might have travelled lightly, as it would have appeared in manuscripts, jewellery, textiles, and embroideries, and that it was not necessarily linked to the space of the church building, even though this is where it has survived. In my survey of the Scandinavian material, I have come across approximately eighty examples of the motif from the medieval period, but surely, there are many more to be found, and only a few of the cases may be discussed below. The motif features a number of minor variations, of which some are of major theological significance, but these were in all likelihood not local inventions. Rather, they reflect that a multitude of iconographical models were available.

With the possible exception of the murals of Torpa, the earliest preserved Scandinavian depictions of the Presentation are found on Scanian and Gotlandic baptismal fonts. ${ }^{53}$ The Kropp font is dated to the first half of the twelfth century. ${ }^{54}$ In Signums svenska konsthistoria the motif on the Kropp font is described as

53 In the Torpa murals, the temple of Jerusalem is represented by a ciborium, carried upon four columns, just like we often see in the late medieval southern European tradition. Torpa is dated to the mid- or late twelfth century, however recent dendrochronology points towards the 1120s as building period for the church, and Byzantine elements surface both in style, iconography, and through the use of the pigment ultramarine. For the latest references to this discussion, with references to previous contributions, see Anders G. Nord et al., "Pigmentanalys av 1100-talsmålningarna i Torpa kyrka, Kungsör," Fornvännen. Journal of Swedish Antiquarian Research (2017): 73-9. The most recent contribution to the discussion of the Gotlandic fonts are Evert Lindkvist, Gotlands romanska stenskulptur: Visuella budskap i sten (Stockholm: Gotlandsboken AB, 2015); Harriet Sonne de Torrens, "De fontibus salvatoris: A Liturgical and Ecclesiological Reading of the Representation of the Childhood of Chris ton the Medieval Fonts from Scnadinavia" ( $\mathrm{PhD}$ Thesis, University of Copenhagen, 2003), and Folke Nordström, Mediaeval Baptismal Fonts - an Iconographical Study, Acta Universitatis Umensis (Umeå - Stockholm: Almquist and Wiksell, 1984). The study of Roosval from 1918 is also still important. Roosval ascribed the Sanda font to the "Byzantio workshop," and the Väskinde font to the "Majestatis workshop." Jonny Roosval, Die Steinmeister Gotlands (Stockholm: Fritze, 1918).

54 Monica Rydbeck, Skånes stenmästare före 1200 (Lund: Arkiv för dekorativ konst, 1936), 296. 


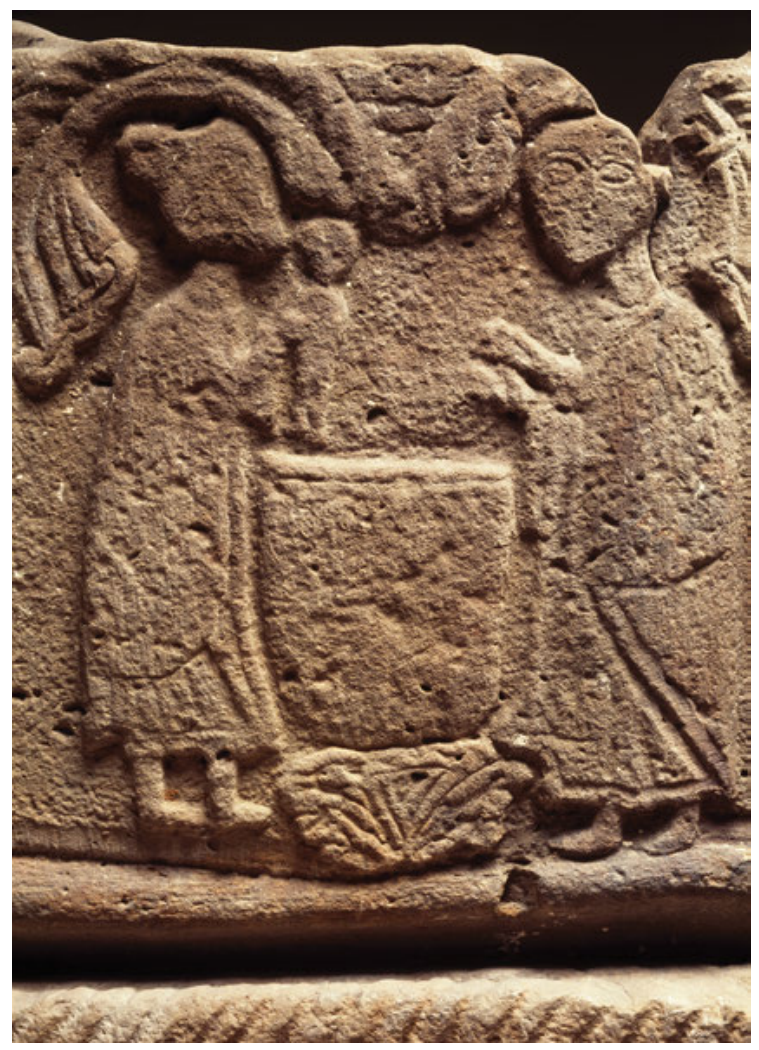

Fig. 17.2: Presentation in the Temple. The Kropp baptismal font, 1100-1150. The National Historical Museum, Stockholm.

baptism, but at this point in time and in this medium, the depiction of contemporary ritual would be almost unthinkable, and moreover, the composition follows the typical arrangement of the Presentation (Fig. 17.2). ${ }^{55}$ On the Kropp font, the scenes are set beneath arcades, which is the typical arrangement of the baptismal fonts of this date, but for the Presentation scene spanning across two arches, the column is omitted allowing room for the significant iconographic and theological element of the altar. ${ }^{56}$ Simeon wears a pointed hat signifying his Jewish identity, and his hands appear to be covered with cloth, as described in the Pseudo-Matthew. Mary presents

55 Jan Svanberg, “Stenskulpturen," in Signums svenska konsthistoria. Den romanska konsten, ed. Lennart Karlsson, et al. (Lund: Bokförlaget signum, 1995), 126. The baptism of Christ is not unusual on Scandinavian Romanesque fonts, but never the actual ritual. On the Kropp font, Mary and Simeon have switched places, but his is not uncommon in the early Scandinavian material.

56 Also von Erffa notes that the Temple is depicted in various ways, but the altar is mostly there, and in the later Middle Ages this is often covered by a ciborium. Objects (like the offerings) are sometimes placed upon it, Hans Martin von Erffa, "Darbringung im Tempel," in Reallexikon zur deutschen Kunstgeschichte, ed. Otto Schmit (Stuttgart: Alfred Druckenmüller Verlag, 1954), 1063. 


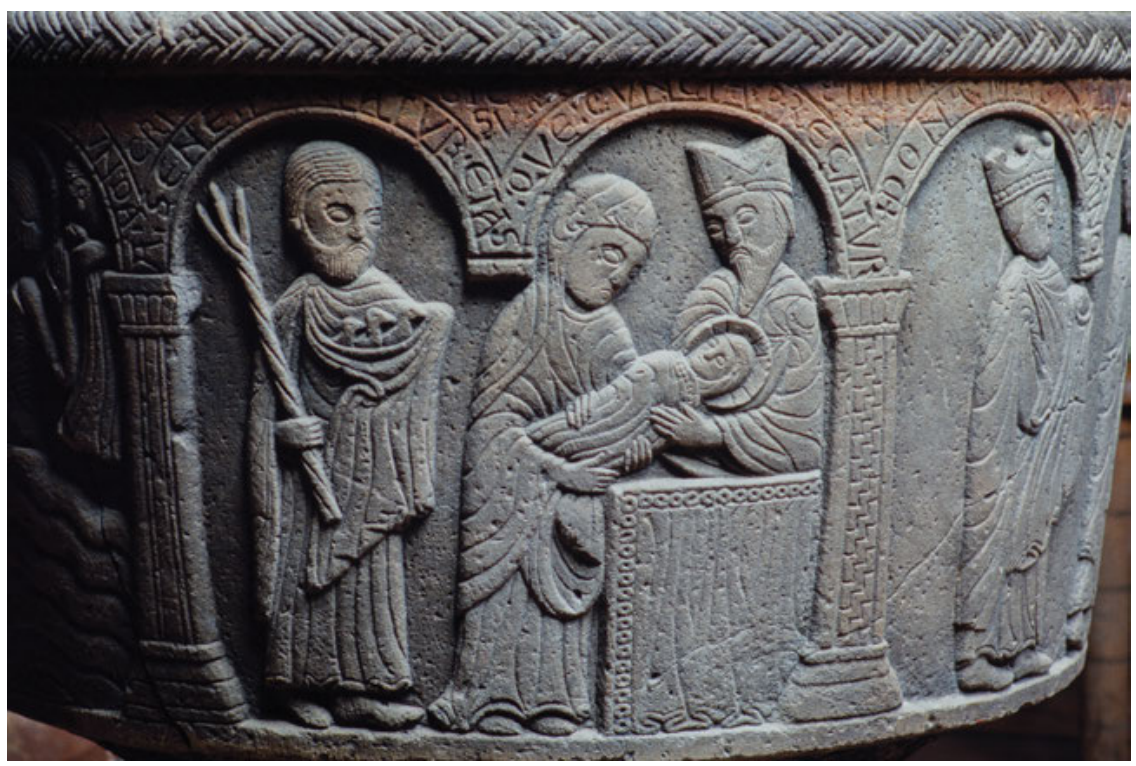

Fig. 17.3: Presentation in the Temple. The Gumlösa baptismal font, c.1190, Gumlösa Church, Scania.

the child to Simeon. ${ }^{57}$ In Kropp Joseph is not present. Only the theologically most significant characters are depicted; the biblical script is thus cut short in order to make a theological point, a strategy that is not unique to Kropp.

On the Gumlösa font (c.1190) the important iconographical element are the offerings (Fig. 17.3). Mary brings her sacrifice, the child, and holds him out to Simeon above the altar. The child is paralleled in Joseph's three-branched candle, and his basket of three doves. Simeon is portrayed with a mitre; an early example of a European convention popular in German areas, again demonstrating that a number of continental models were by then available to the southern Scandinavian artists. ${ }^{58}$

The Gotlandic font from Vall (c.1200) is ascribed to the "Majestatis-workshop" (Fig. 17.4), and with its remains of original paint it gives a vivid impression of the original appearance of these fonts. ${ }^{59}$ Vall introduces yet another significant theological

57 Svanberg, "Stenskulpturen," 126.

58 Sonne de Torrens, "De fontibus salvatoris," II, 37. Sonne de Torrens dates the font to 1191. See also Nordström, Mediaeval Baptismal Fonts, 109; Roosval, Die Steinmeister Gotlands, 124; Rydbeck, Skånes stenmästare före 1200, 308. On the comparative perspective of Simon as bishop or high priest, see von Erffa, "Darbringung im Tempel," 1063. According to von Erffa, this is a convention which do not appear until the thirteenth century.

59 In the case of Väskinde, like Kropp, Mary and Simeon have switched places, but later paint has wrongfully put them in their usual place, but the person reaching out for the Christ child is certainly vailed and must be identified as Mary. 


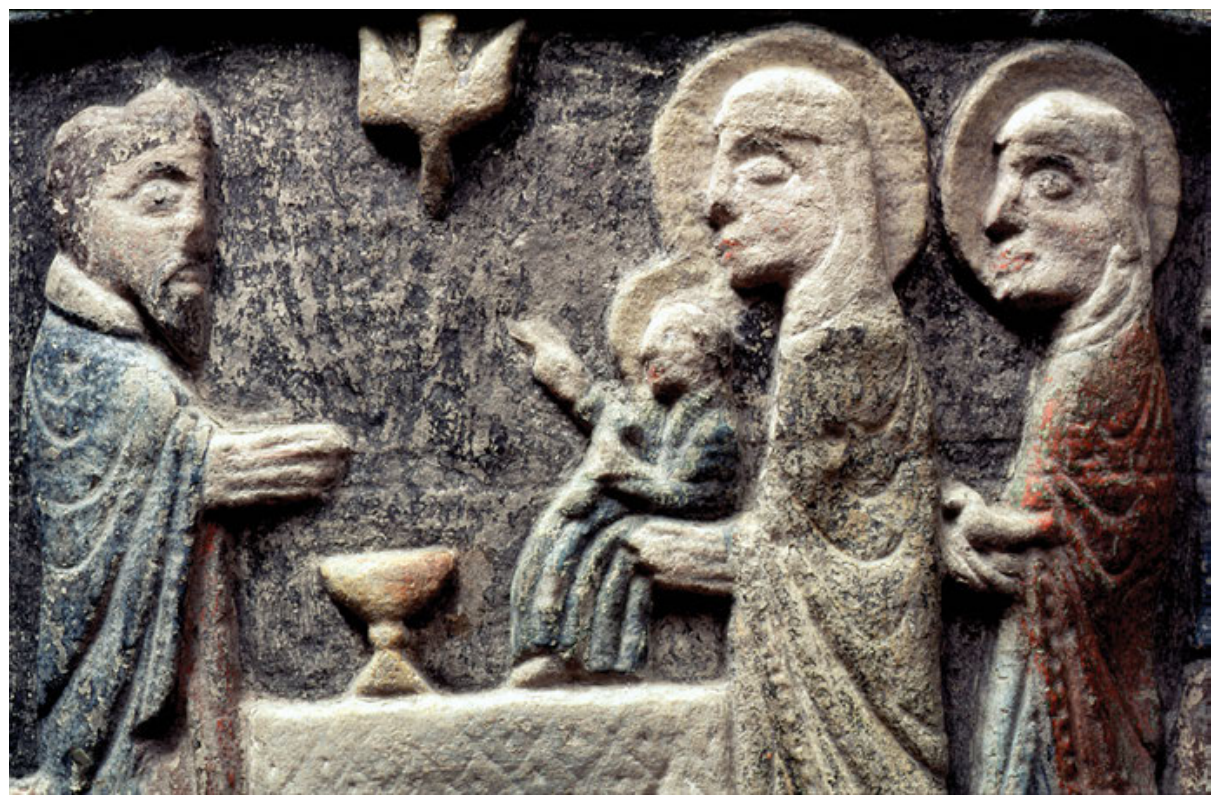

Fig. 17.4: Presentation in the Temple. The Vall baptismal font, c.1200, Vall Church, Gotland.

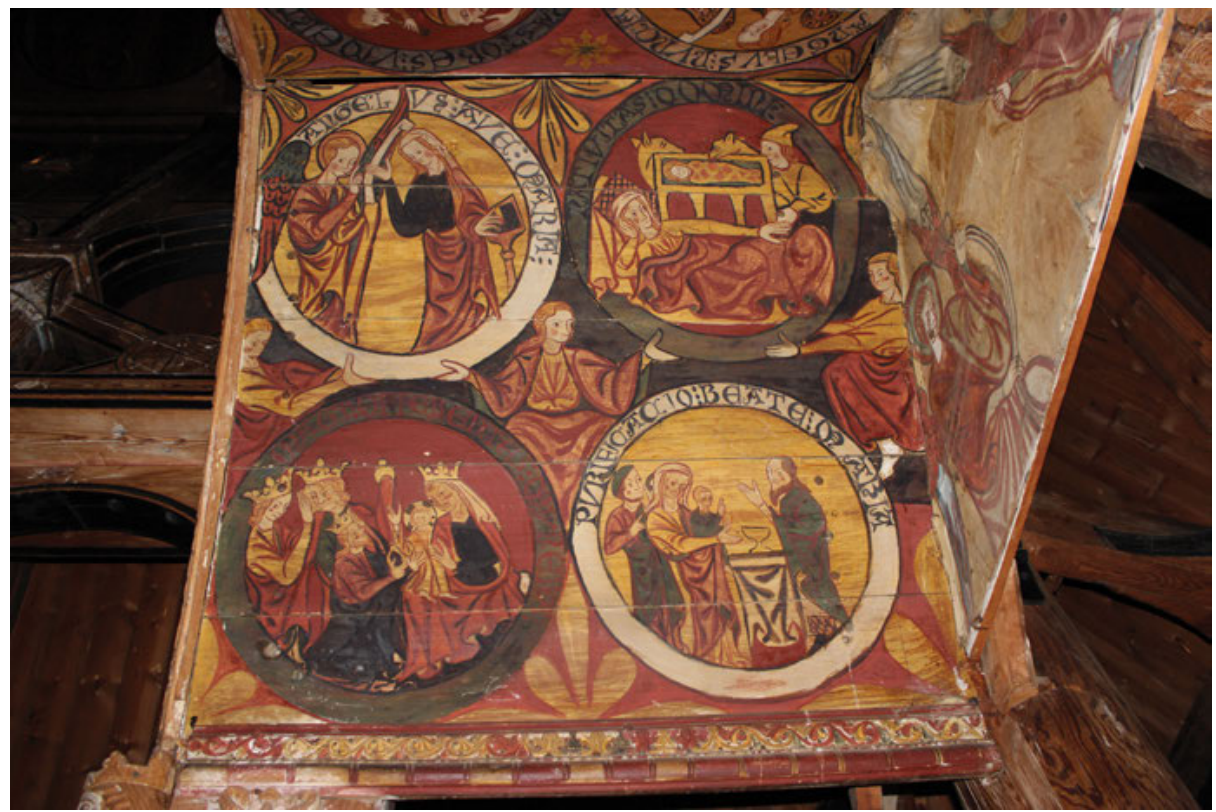

Fig. 17.5: Childhood of Christ scenes, the Hopperstad Ciborium, c.1300, Hopperstad Church, Sogn. 
motif. Down towards the altar dives the dove; the Holy Ghost who had promised Simeon he would see the Messiah. Another interesting element in the Presentation scenes from the "Majestatis-workshop" is the chalice. Placed upon the altar the chalice points towards the sacrifice of Christ and to the transubstantiation of the blood of Christ in communion. Albeit never a common fixture, this element is later frequently found in the Scandinavian material. The Norwegian Hopperstad ciborium (c.1300) (Fig. 17.5) even shows Mary gesturing towards the chalice, which is placed upon the otherwise bare altar, and in the ill-preserved murals of the chapter house of St Birgitta's Vadstena (c.1370-1380), we see not the sword of her vision, but the chalice. ${ }^{60}$

The sword does however appear also in the Scandinavian material. Although they are much damaged, the murals of Kumlaby in Småland (c.1475-1500) show the sword of Simeon's prophecy and St Birgitta's vision, piercing Mary's heart. ${ }^{61}$ The reference to the offering she will have to make, is enforced by the Christ Child who stands upon the altar. Hans Martin von Erffa describes this type as Schmertzenmutter, and associates the convention as such to the Dominicans, who attached great mysticism to the sword. ${ }^{62}$ To my knowledge, Kumlaby is the only example of a Presentation with a Schmertzenmutter in Scandinavia.

To the storyworld of the Presentation belongs also "the other woman." Already in the works of the above mentioned Majestatis-workshop, we see a woman accompanying Mary. This accompanying woman becomes something of a fixture. In fact, like in St Birgitta's vision, Joseph is often simply omitted. The woman who takes his place, or is added, is sometimes nimbed, and sometimes not, she sometimes holds the offering of the doves and/or a candle. The question is who this woman is; or rather, what her role is. Does she reflect the contemporary situation of medieval women, who would not come to their churching without an accompanying woman, or does she belong within the biblical narrative, or within theological commentary?

In the late medieval tradition south of the Alps we find Anna the prophetess placed beside Simeon, compositionally balancing Joseph. She has the appearance of an older woman, and holds the tablets of the law. The offering of the doves might however very well have been considered a suitable attribute for Anna the prophetess, who was a widow, and who had only had the one husband (Luke 2:36-37). In medieval theological texts, the turtledove was a well-known symbol of chastity. ${ }^{63}$ According to

60 Mereth Lindgren, "Kalkmålningarna" in Signums svenska konsthistoria. Den romanske konsten, ed. Lennart Karlsson, et al. (Lund: Bokförlaget signum, 1995), 358-60. Nisbeth interprets the object upon the altar as a candle. Åke Nisbeth, Ordet som bild. Östgötskt kalkmåleri vid slutet av 1300-talet och början av 1400-talet, Scripta maiora (Stockholm: Runica et mediævali, 1995), 16, $18,223$.

61 Bengt Söderberg, De gotländska passionsmålningarna och deras stilfränder. Studier i birgittinskt muralmåleri (Stockholm: Akademisk avhandling vid Stockholms högskola, 1942), 334-344; see also English summary in V. Hernfjell, Medeltida kyrkmålningar i gamla Skara stift (Skara: Skaraborgs länsmuseum, 1993), 220. Hernfjell dates Kumlaby to c.1480.

62 von Erffa, "Darbringung im Tempel," 1068.

63 Lasse Hodne, "The Turtledove: A Symbol of Chastity and Sacrifice," IKON 2 (2009): 159-66. 
the bestiaries, the turtledove is a bird which at the loss of his mate never ceases to mourn for him and never seeks a new companion, and in the Middle Ages, the turtledove figures as an allegory both for virginity, widowhood, and chastity. ${ }^{64}$

When the additional woman holds a candle, the identification is somewhat less obvious, but given Anna's proclamation of Christ as the redeemer, the candle might still be a suitable attribute. Notwithstanding, the contemporary ritual situation should also be considered. ${ }^{65}$ It is tempting to simply conclude that when the accompanying woman has a halo, she is to be identified as Anna the prophetess; but when she is not nimbed, she is a maid, midwife, or another accompanying woman known to have been present at women's churching many places in Europe. ${ }^{66}$ Still, only Christ is always nimbed (with the exception of the Hopperstad ciborium, cf. Fig. 17.5), all the other characters in the biblical script, may or may not wear a halo. To complicate things further, haloes were often amongst the details added to the work by the painter, and since the original polychrome is often missing, this may lead to erroneous conclusions. In his discussion of the German material, Hans Martin von Erffa notes that from the twelfth century on, Mary is often accompanied by a nimbed young woman, carrying a cross or the offering, and because she is nimbed, he interprets this as a female saint. ${ }^{67}$ If he is right, then an eschatological dimension is added to the scene: it certainly becomes one of a "heavenly feast," and not one located in an, albeit distant, yet historical past.

From Norway, six altar panels are preserved which include the motif of the Presentation (dating from 1250-1350). ${ }^{68}$ These are particularly interesting as they actually once adorned physical altars set within the local churches. In the Scandinavian versions of the Presentation, the temple is constituted by the presence of the altar. There are, however, cases in which more attention is given to the temple of Jerusalem, as it was imagined by the medieval artist. In the Skaun frontal (c.1250), there is, in addition to the traditional centrally placed altar, a baldachin hovering in the air behind Simeon (Fig. 17.6). Its roof is like the roof of a church, but the corners are not carried

64 Hodne, “The Turtledove," 159-66, and in particular n.19.

65 Gertrud Schiller does not note the presence of the candle in the iconography of the Presentation until the twelfth-century, and in the German material, presumably influential in the Swedish realms, it is not commonly found until the later Middle Ages, Gertrud Schiller, Iconography of Christian Art, vol. 1 (New York: New York Graphic Society, 1971), 90-1.

66 Susan K. Roll, “The Old Rite of the Churching of Women after Childbirth,” in Wholly Woman, Holy Blood: A Feminist Critique of Purity and Impurity, Studies in Antiquity and Christianity, ed. Kristin de Troyer (Harrisburg - London - New York: Trinity Press International, 2003), 127.

67 von Erffa, "Darbringung im Tempel,” 1067-1068. Von Erffa moreover suggests that when the accompanying woman is older looking, yet nimbed, this might be Elizabeth, which is common in the Baroque period.

68 These are Skaun (c.1250), Tingelstad (c.1275-1300), Hamre (c.1300), Dale I (c.1325), Filefjell (c.1325), and Tresfjord (c.1325-1350); see Margrethe C. Stang, "Paintings, patronage and popular piety. Medieval altar frontals and society c.1250-1350” (PhD Thesis, 2009), 81. 


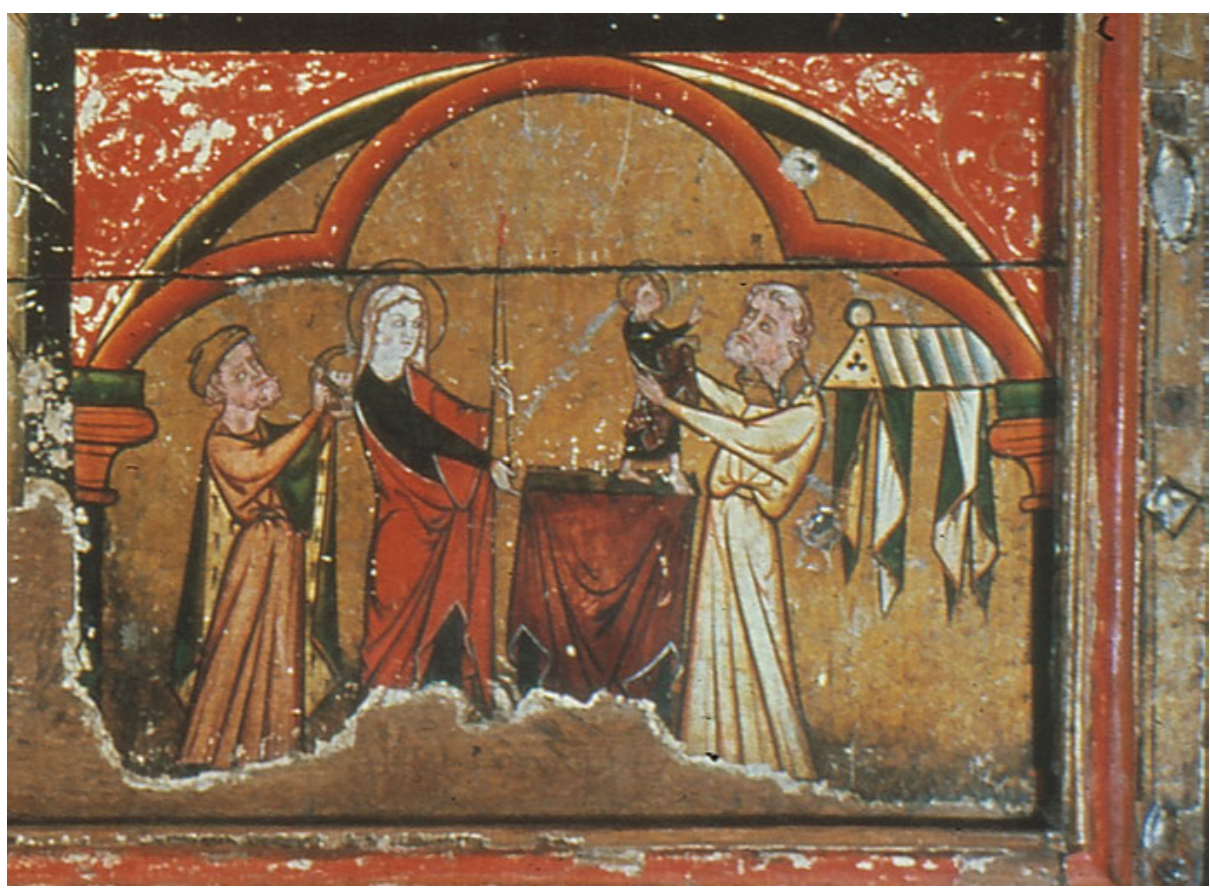

Fig. 17.6: Presentation in the Temple. Detail of the Skaun altar panel, c.1250, Skaun Church, Trøndelag.

by columns, rather, curtains are hanging from them. This would probably be rather typical for canopies of the thirteenth- and fourteenth centuries; in the local churches holy objects connected to Mass and Last Supper were often protected by such altar curtains. Thus, not surprisingly, the canopy in the Skaun frontal seems to be a projection of the contemporary situation upon the biblical one. As in the liturgy, the here and now merge with the distant past.

The altar panel from Tresfjord (c.1325-1350) features the Christ child standing upon the altar, which is a very common iconographical type in late medieval Scandinavia (Fig. 17.1). Like the chalice, the standing Christ child clearly points forward towards his sacrifice, and to the transubstantiation, making his presence explicit. Moreover, the Tresfjord Christ child holds up his hand to bless Simeon, an element also found in the Filefjell panel (c.1325), and in the above-mentioned vault of the Hopperstad ciborium (Fig. 17.5). In Hopperstad, the scene is found under the heading In Purificatio beate maria, the name of the liturgical feast. ${ }^{69}$ of course, the blessing is not as such part of the biblical script; rather, it belongs

69 The hands of Simeon are here not covered, indicating the heritage of the Vulgate text rather than the much more common form from the Pseudo-Matthew, nor are any of the characters nimbed. 
within theological commentary making clear what is in fact happening; for Christ's reception in the temple foresees the redemption of mankind.

The blessing Christ Child is however a type which appears in the arts from the ninth century on, as seen in the Drogo Sacramentary and in the Anglo-Saxon Benedictional of St Æthelwold, where it accompanies the prayer for the blessing of the candles. ${ }^{70}$ In several of the altar panels, the virgin holds a candle. Discussing the Norwegian panels, Nigel Morgan interprets this element as an allusion to the blessing of the candles on Candlemas. ${ }^{71} \mathrm{We}$ may not know at which altar the blessing of the candles took place, but where this was depicted on the altar panel, the image may well have functioned as it did in St Æthelwold's Benedictional; as a visual commentary to the rite. The early fourteenth-century door to the Sacramental niche from Gotlandic Bunge (Fig. 17.7) for instance features the scene of the Presentation, and above it, two angels hold a candle, crowned by the head of Christ. ${ }^{72}$ Again, the iconography and the compositional choices made, the medium, and the ritual, constitutes a liturgical whole. The imagery works together with the ritual in bridging the distant past with the present. Equally important to bridge this temporal gap, was the ritual of Churching, which offered another way for the medieval worshiper to engage with the past.

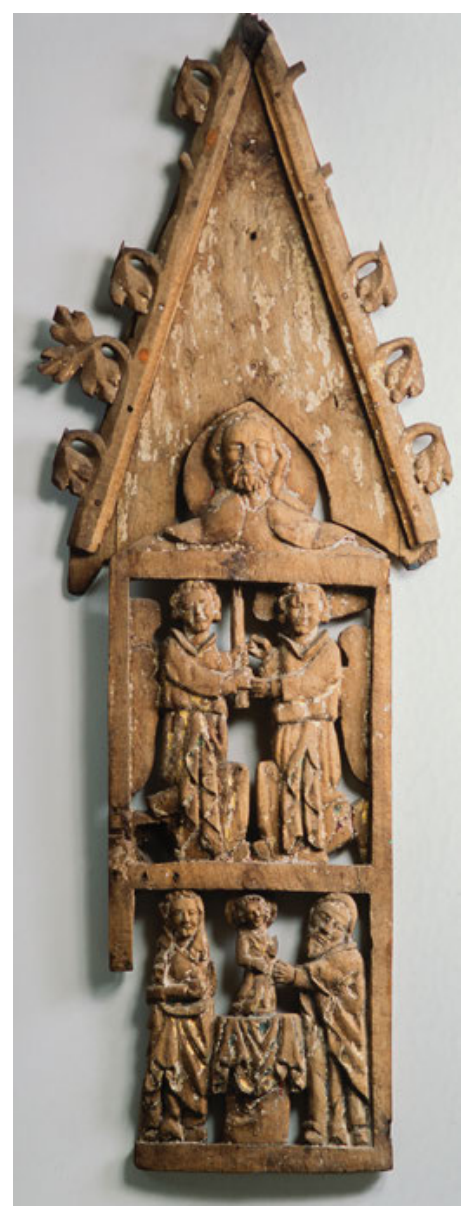

Fig. 17.7: Door for sacramental niche, early fourteenth century, Bunge Church, Gotland.

\footnotetext{
Albeit of rather poor artistic quality and inaccurate Latin, the level of theological commentary is high. For a discussion of the Hopperstad ciborium, see Tone Sofie Gjesdahl, "Hopperstadciboriet" (Master Thesis, University of Oslo, 1968).

70 St Æthelwold's Benedictional, BL Add 49598, f. 33 and 34.

71 Unn Plahter et al., Painted altar frontals of Norway 1250-1350: An Art-historical and Technical Study of the 31 Painted Panels Preserved, 3 vols. (London: Archetype Publishers, 2004), I, 46.

72 Justin Kroesen and Peter Tångeberg, Die mittelalterliche Sakramentsniche auf Gotland (Schweden). Kunst und Liturgie (Petersberg: Michael Imhof Verlag, 2014), 134-5. For a general overview, see Medeltidens bildvärld, Historiska museet, Stockholm, http://medeltidbild.historiska.se, "Bunge.”
} 


\section{The Ritual of Churching and Its Impact on the Motif of the Presentation in the Visual Art}

It is presumably no accident that no prescription for this often-performed ritual has been preserved from medieval Scandinavia, although documentary evidence in the form of charters, laws, letters, and murals testify to its common practice. Churching was not a sacrament, it did not concern the souls' salvation, it did not commemorate a moment of Revelation, nor a significant moment in the Life of Christ; in fact, it was theologically marginal. Rather, it was important in a social context, and it lived on in Scandinavia for almost a millennium, well beyond the Protestant Reformation, as we shall see below. The Candlemas sermon in the Norwegian Homily Book points out that even though Mary and her son were never impure, and no offering was needed, Mary still honoured the Law, thus the sermon encourages the ritual of churching. ${ }^{73}$ This was no invention of the local scribe, but a theme that may be recognized in earlier sermons, as for instance in the Anglo-Saxon sources. ${ }^{74}$

The origin for the ritual of the Purification of women is found in the Old Testament custom described in Leviticus, Lev 12:1-8. Here, it is decreed that if a woman bears a boy child, then she shall be unclean for thirty-three days, and for this period of time, she shall touch no holy thing, nor enter into the sanctuary, until the days of her purification are fulfilled, but if the child is a girl, she shall be unclean for sixty-six days. The number of days a woman was considered impure differed in medieval practices. ${ }^{75}$ Although early medieval customs of separation may have been influenced by Mosaic law, they were not merely an adoption of such. ${ }^{76}$ The first official document which dates from c.600, is a letter discussing the matter, from Gregory the Great to St Augustine of Canterbury. ${ }^{77}$ Gregory here expresses a notion also later met with in medieval writing, namely that the new mother first and foremost is impure from the sin of lust related to intercourse, and not primarily from blood. Gregory also notes that a woman who enters the sacred space before her time of exclusion is over, in order to

73 Gamal norsk homilebok: Cod. AM. $6194^{\circ}$, ed. Gustav Indrebø, Oslo: Kjeldeskriftfondet, 1966.

74 Bedingfield, The dramatic liturgy of Anglo Saxon England, 60.

75 Roll, "The Old Rite of the Churching of Women," 124. The Norse biblical compilation Stjórn II says that the woman is not to enter the church for thirty-seven days if she has given birth to a girl, and for fifty-four days if she has born a boy. During this time, she shall first stay in bed, but for the last thirty days she must stand outside, but not enter the church, Reidar Astås, "Spor av teologisk tenkning og refleksjon i norsk og islandsk høymiddelalder," Collegium Medievale. Interdiciplinary Journal of Medieval Research 6 (1993): 156 n.97.

76 Paula M. Rieder, On the Purification of Women. Churching in Northern France, 1100-1500, The New Middle Age (New York: Palgrave Macmillan, 2006), 14-37. For a critical survey of the ritual up until the twentieth century, see Roll, “The Old Rite of the Churching of Women,” 117-42.

77 Rieder, On the Purification of Women, 21-2; Roll, "The Old Rite of the Churching of Women," 122-30. 
offer her thanks, does not pollute the sacred space. ${ }^{78}$ Such prescriptions for a woman's conduct in relation to the sacred following the birth of a child is also advocated in Honorius' Gemma Animae, in his book one, chapter CXL VI, under the section De mulieribus. ${ }^{79}$ Honorius lists several reasons why a woman is impure, including being impure form original sin, and clearly reflects the writing of Gregory when he says that a woman must not enter the temple unless it is to give thanks. Honorius' Gemma anima was widely used in Scandinavia from the late twelfth century on.

The first Scandinavian references to the ritual of Churching are found in the Norse laws, put into writing in the twelfth century, but sections of these laws are certainly older. The ritual is mentioned in relation to spiritual kinship. ${ }^{80}$ Apart from indicating that the ritual might have been commonly practiced in the twelfth century or even earlier, these laws confirm that it was a ritual element to lead the woman in, and that this was not necessarily done by the priest. The Church section of Upplandslagen (the Uppland law) from late thirteenth-century Sweden also concerns Churching. ${ }^{81}$ The law states that the woman should pay a fee or give the priest a vax candle on the occasion of her Churching. The ritual moreover appears in other legal sources, such as the town law of Gotland, attempting to regulate the number of accompanying women. ${ }^{82}$

Numerous sources from the time of the Lutheran reformation mention the ritual of Churching, letting us know how it was then performed and perceived. Representing the Catholic perspective, Olaus Magnus writes that forty days after giving birth, women must go to be purified at the church door, carrying candles, and that this shall be done by example and resemblance. ${ }^{83}$ Educated from Wittenberg, the Danish reformer Peder Palladius (1503-1560) who returned to Denmark in 1537, took quite a different view. Palladius became the first Lutheran bishop of Zealand, and from his visits to his

78 "For if she enters the church even at the very hour of her delivery, for the purpose of giving thanks, she is not guilty of any sin: it is the pleasure of the flesh, not its pain, which is at fault." Bede the Venerable, Bede's Ecclesiastical history of the English people, trans. R.A.B. Mynors, ed. B. Colgrave, Oxford: Clarendon Press, 1969.

79 Honorius Augustodunensis, Gemma Animae, PL, 172, cols 541-738, Liber I, cap. CXL VI: “De mulieribus."

80 Old Gulathing mentions the one who " . . . leads the mother into the church," as someone one may not marry, whereas Old Eidsivathing states that the one who one leads into church, one may marry. The Earliest Norwegian Law: Being the Gulathing Law and the Frostathing Law, trans. Laurence Marcellus Larson, New York: Columbia University Press, 1935; Eidsivatings eldre kristenrett, ed. E.F. Halvorsen and M. Rindal, De eldste østnorske kristenrettene, Norrøne tekster, 7, Oslo: Riksarkivet, 2008. For a survey of the sources and the practice in the northern countries, see M. M. Larússon, "Kyrktagningen," in KLNM, 21-5.

81 Upplandslagen enligt Codex Esplunda, ed. Samuel Henning, Uppsala: Almqvist \& Wiksell, 1935, s.v. "Kyrktagningsbalken".

82 Uplands-lagen, ed. H.S. Collin and C.J. Schlyter, Corpus iuris Sueo-Gotorum antiqui = Samling af Sweriges gamla Lagar, 3, Stockholm: Haeggström, 1834, section 4, ch. 18.

83 Olaus Magnus, III, 77. 
diocese, steams his Visitation book. Under the section “Women's offering,” Palladius writes that when women were in bed after childbirth, people used the expression "she laid a heathen" [hun laa hienske], because the monks had taught them that such women belonged to the devil, and accordingly, she needed light and water. ${ }^{84}$

The decrees of a Lutheran bishops' synod held in Copenhagen in 1540 states that a woman may choose to have her Churching, but she may not carry the candle, nor may she be introduced by the hand of the priest. ${ }^{85}$ In 1542 Churching was in theory abolished. ${ }^{86}$ Nonetheless, the 1573 Stavanger synod disapprovingly notes the continuous use of candles, but also that after the entry, the practice varied. Some places women returned to their bench, whereas other places, the women should stay near "a heathen altar" [et affgudisk altere], presumably (side) altars remnant from before the Reformation, like a Marian altar. ${ }^{87}$ In 1580, Jens Nilssøn, bishop of the diocese of Oslo and Hamar, complained that some places women still carried candles, and knelt in the church door before their entry. ${ }^{88}$

To attain a better understanding of the actual ceremony, we shall however have to turn to comparative European material. In his study of medieval benedictions, Adolph Franz reproduces seven text fragments of the ritual from the eleventh and the twelfth centuries. $^{89}$ One of Franz's cases is found in a Pontifical now in Trinity College, Cambridge. ${ }^{90}$ Here, the bishop is vested in his cope, with mitre and staff, as he proceeds to the church door, with his ministers, reminding us of the pictorial convention seen in the Gumlösa font, with Simeon as bishop (Fig. 17.3). After psalms, prayers, and benedictions, the woman is aspersed and led by the right hand into the church, they approach the altar and Mass is sung. Another of the texts reproduced in Franz's study is from Salzburg, from the eleventh or twelfth century. ${ }^{91}$ The ceremony starts with the woman standing outside, while psalms are sung (Pss 112, 127). Then benedictions are said, before the woman is led by the right hand into church. The text prescribes that she shall prostrate, while they sing Cor mundum (Ps 50/51), which is part of the seven penitential psalms which concerns the repentance from grave sin, and one which was commonly used for rogation processions, and for the expulsion and reconciliation of the public penitents. In the latter case, prostration would also accompany this psalm,

84 Peder Palladius, Visitatsbog, ed. A.C.L. Heiberg, Copenhagen: Samfundet for den danske Litteraturs Fremme, 1867: “Om Kvindeoffer” and "Hvorledes det skal gaa til med Kirkegang." Palladius recommends that when the woman arrives at the church door, she shall not ask for "water and candle," but merely ask that the minister pray for her. Afterwards, while inside the church, the mother and the women accompanying her may approach the alter with their offerings, and thank God.

85 H. Fæhn, Gudstjenestelivet $i$ den norske kirke (Oslo: Universitetsforlaget, 1994), 117-8.

86 Fæhn, Gudstjenestelivet, 117.

87 Fæhn, Gudstjenestelivet, 118.

88 Fæhn, Gudstjenestelivet, 118-20.

89 Die kirchlichen Benediktionen im Mittelalter, ed. A. Franz, II, Freiburg im Breisgau: Herder, 1909.

90 Die kirchlichen Benediktionen, 228 n.3.

91 Die kirchlichen Benediktionen, 224, listing his sources as CVP 2090, BL. 95. 
thus the reference to penance would not only happen through music and lyrics, but also through physical performance. Of course, impurity and penance were bound together in medieval Christianity, but only three of the texts reproduced in Franz specifically refer to Leviticus. ${ }^{92}$

Most of the texts however carry a reference to the Purification of Mary, and most have the Collects from Candlemas. ${ }^{93}$ Other texts, like the twelfth-century benedictions from Wessobrunn, prescribes the Prologue to John, which speaks about Christ as “. . . the true light, which enlighteneth every man that cometh into this world" (John 1:9), quite directly making a reference to "a light to the revelation of the Gentiles" (Luke 2:32), and the light the woman herself carried as she entered her local temple.

In Churching, the candles served both as offerings and as signifiers of the women's social and religious status. A Norwegian charter from 1303 mentions the going rate for women's Churching, where they are to bring offerings of candles and cloth. ${ }^{94}$ Carrying the light of Christ was not for those who had not honoured the Law. An Icelandic statute issued by Magnús Gissursson, bishop of Skálholt in 1224, states that only those who had conceived the child within wedlock were allowed to enter the church with their candle burning, the others might enter, but not with a candle. ${ }^{95}$ In the same manner, a woman holding a burning candle led the funeral procession of an honourable woman dying in child birth, but had the child not been conceived by the husband, the law forbade a burning candle. ${ }^{96}$ In the early fourteenth-century statutes of Archbishop Eiliv of Nidaros (d. 1332), women who had conceived either outside wedlock or by men in forbidden relations were simply not to receive Churching; a view which was upheld also after the Lutheran Reformation. ${ }^{97}$ Similarly, one of the preserved Norwegian marriage rituals prescribes that after their union is blessed by God, the couple shall carry burning candles as they enter the church, and in the Nidaros province, excommunication might even be proclaimed with candles turned upside down. ${ }^{98}$ No doubt, the lit candle was the sign of a soul who had received Christ and lived by his words; the extinguished candle signified the opposite, and embodied a reference to future judgement. ${ }^{99}$

92 Roll, "The Old Rite of the Churching of Women," 126-7.

93 Die kirchlichen Benediktionen, 229.

94 DN, vol. 3, no. 65 (dates 1306); DN, vol. 5, no. 43 (dated1303).

95 DN, vol. 1, 117.

96 Árna saga biskups, ed. P. Hauksson, Reykjavík: Stofnun Árna Magnússonar á Íslandi, 1972.

97 “Archbishop Eiliv's third statue,” in Norges Gamle Love indtil 1387, ed. E. Hertzberg, et al., vol. III, Lovgivningen efter Kong Magnus Haakonssøns Død 1280 indtil 1387 (Christiania: Chr. Grøndahl, 1849), 261. See also Larússon, “Kyrktagningen,” 21-5.

98 Laurentius saga Hólarbiskups. Eptif sira Einar Haflidason, ed. Jón Sigurðsson, et al., Biskupa Sögur, 1, Kaupmannahöfn: Hinu Íslenzka Bókmentafélagi, 1858, 787-914; Manuale Norwegicum, 22. 99 With the reformers, the custom of introducing the deceased mother was abolished. In the thirteenth-century Icelandic ones the coffin was introduced to the church, preceded by a person 
The Norwegian homily book explains that the use of candles in the Candlemas celebration signify how the just through their good deeds will come to heaven. ${ }^{100}$ The author links the ritual here and now with the biblical message, by pointing out that today they stand in church with their candles burning, for the gospel says that they shall be dressed ready for service, and "keep their lamps burning," and that they shall "let their light shine before others," that they may see their good deeds and glorify the Lord (Luke 12:35; Matt 5:16). With such reference, the parable of the wise and foolish virgins (Matt 25:1-13), and the idea of the woman as bride, are brought into the cluster of metaphors utilized both in the ritual of Churching and in the Candlemas celebration. In the well-known story of the wise and foolish virgins, the maidens may not know when the groom will arrive, but the wise virgins stay prepared, so that when he comes, they go to greet him with their laps lit. They go in with him for the wedding, and the door is shut. The foolish virgins have no oil for their lamps, they go out to buy it, and hence they are not there to greet their bridegroom at the hour of his arrival. The symbolism is not hard to make out, and the allusion between the narrative from Luke (2:22-38) and the parable of the wise and the foolish virgins is also made in medieval theological commentary, as for instance by the French theologian Guillaume Durand (c.1230-1296), another liturgist whose books could be found in the library of the Nidaros' archbishop.

There is thus a high degree of inter-referentiality in the rituals for Candlemas and the reconciliation of woman after childbirth. This web of references would presumably not have been lost on the women; the entry in the temple of Jerusalem was simultaneously created and re-created, and the reference to her own salvation explicit and obvious. The participant would recognize the music, the offering, the use of candles, and the act of entry.

There were also social aspects to the ritual of Churching. St Birgitta's vision, quoted at the beginning of this chapter, opens with the image of a great feast, very possibly influenced by the feast hosted by herself and other women of her standing on the event of their Churching, allowing the woman to be the centre of attention. Discussing Churching in late medieval England, Gail McMurray Gibson argues that Churching afforded women a sense of empowerment; the woman, and her body, were the symbolic and ritual centre of this drama, together with the women who had served as childbed attendants in the exclusive female space of the childbirth room. ${ }^{101}$ The feast connected to this ritual is also mentioned in the textual sources

carrying an extinguished candle, and the mother was dressed in grey garments, Bjarne Stoklund, "Kyrktagning," in KLNM, 21-4.

100 Gamal norsk homilebok, 66-9.

101 Gail McMurray Gibson, "Blessing from Sun and Moon: Churching as Women's Theater," in Bodies and Disciplines: Intersections of Literature and History in Fifteenth-Century England, ed. Barbara Hanawalt and David Wallace, Medieval Cultures (Minneapolis: University of Minnesota Press, 1996), 149. 
from the later Middle Ages and the time of the Lutheran Reformation. ${ }^{102}$ Attempts were made to regulate both the feast and the lavishness of the ritual. The celebration of the reconciliation of women would certainly have been an indicator of social status, for instance through the number of women accompanying the new mother, the lavishness of their dress, the use of candles, and through the level of festivity that followed the ecclesiastical ceremony. ${ }^{103}$ In 1336 the town council of Slesvig set the limit to a maximum of six accompanying women, something that was later echoed in the legislation of Husum. ${ }^{104}$ The fourteenth-century laws of the wealthy merchant town of Visby, capital of the Swedish island Gotland in the Baltic sea, however goes much further. In the Visby legislation, it is forbidden for a woman to bring more than 24 accompanying women. ${ }^{105}$

A few late medieval Scandinavian depictions of the Presentation stand out, also compared to the continental material. In these cases, we do not only see a group of women behind Mary, as is often the case in late medieval psalters, but rather a full procession of accompanying women, and the story unfolds over two or more scenes.

The wooden church Södra Råda in Swedish Värmland burned down in 2001, and the many paintings in the interior are now only known from photographs and Mandelgren's drawings from 1849. ${ }^{106}$ The work was signed by Master Amund, and dated 1494. ${ }^{107}$ In the first of two medallions (Fig. 17.8), two nimbed women approach the temple; the main character is the crowned maiden, who holds a lit candle. The older-looking woman in the back carries the traditional basket of doves. Again, there is no Joseph, nor is there a Christ Child. In the next medallion, the fully vested priest awaits the small procession. He is standing in the open door of the stepped gabled west façade of his little church, holding a Mass book and an aspergillum, to sprinkle the woman for her cleansing. Merete Lindgren describes

102 Grethe Jacobsen, Kvinder, køn og købstadslovgivning 1400-1600: lovfaste Mænd og ærlige Kvinder (Copenhagen: Museum Tusculanums Forlag, 1995), 114-5, 46-7; Anders Gustavsson, Kyrktagningsseden i Sverige, Skrifter från Folklivsarkivet i Lund (Lund: Folklivsarkivet, 1972), 123-5.

103 Churching as social display is also brought up in Rieder, On the Purification of Women, 130-2, 65; Roll, "The Old Rite of the Churching of Women," 127. In the same manner, documents from medieval Norway speak of the number of candles, see DN, vol. 3, no. 65; DN, vol. 5, no. 43; DN, vol. 9, no. 186; DN, vol. 9 no. 558.

104 Jacobsen, Kvinder, køn og købstadslovgivning, 146-7.

105 Wisby Stadslag och Sjörätt, ed. H.S. Collin and C.J. Schlyter, Corpus iuris Sueo-Gotorum antiqui = Samling af Sweriges gamla lagar, VIII, Stockholm: Haeggström, 1852, section 4, ch. 18.

106 Hernfjell, Medeltida kyrkmålningar i gamla Skara stift, 104-9; see also Söderberg, De gotländska passionsmålningarna and Svenska Kyrkomålningar från Medeltiden (Stockholm: Natur \& Kultur, 1951); Åke Nisbeth, Mäster Amund och långhusmålningarna i Södra Råda (Karlstad: Värmlands Museum, 1963) and Bildernas predikan: Medeltida kalkmålningar i Sverige (Stockholm: Kungl. Vitterhetsakademien, 1986).

107 Lindgren, “Kalkmålningarna,” 366-9; Hernfjell, Medeltida kyrkmålningar i gamla Skara stift, 166. For the paintings of Södra Råda in general, see also Nisbeth, Mäster Amund och långhusmålningarna i Södra Råda. 


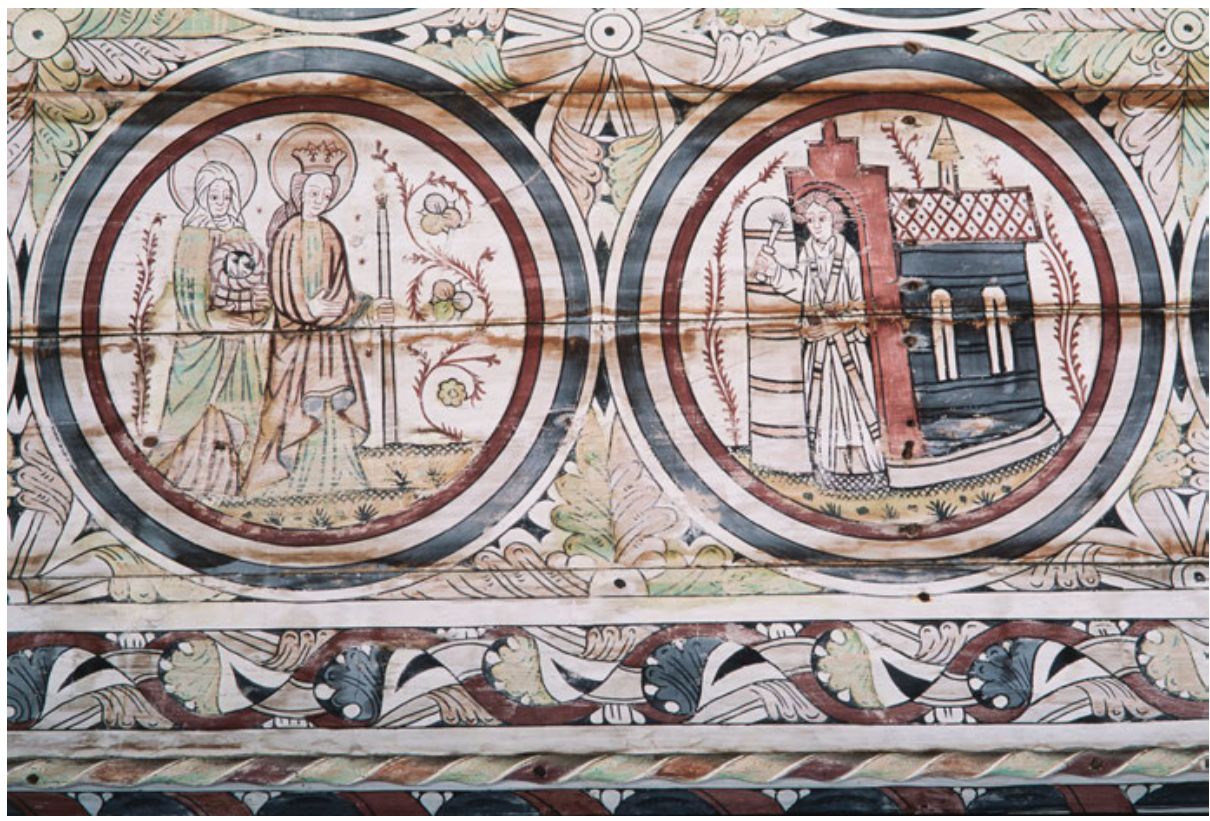

Fig. 17.8: Purification of Mary, Södra Råda Church, 1494, Västra Götaland.

this depiction of Mary's Purification as a medieval Churching. ${ }^{108}$ Mary consistently wears a blue robe in the other medallions of Södra Råda, but the crowned maiden approaching church wears a red robe, yet the sequence within which the motif appears, confirms that this must indeed be Mary's purification. In the murals of Kumlaby in Swedish Småland, attributed to the same workshop, the maiden wears a green robe, not a red as the crown maiden of the previous scene. ${ }^{109}$ It is known from the time of the Lutheran Reformation in Denmark that special robes were worn by the women of the parish for their churching, in some places the robe was even kept in the church and lent to the women and at this point in time the colour

108 Lindgren, "Kalkmålningarna," 370. A third medallion has been described as "the Presentation." Here, we see three nimbed figures; what appears to be the woman of the previous medallion, the Christ Child who stands upon the altar, and a Jewish man behind the altar. With the earlier alter panels in mind, this iconography is unusual. The man is very different from the priest in the door of the previous scene. He wears a beard, a short tunic instead of the vestments of a priest, his hair is longer, and around his shoulders is the tallit, the distinctive Jewish black striped white scarf. It should therefore be considered that this is the Circumcision which is otherwise missing for the sequence, but if so, Christ should not be dressed, and there appears possibly to be some motif-confusion on behalf of the artist, for illustration, see: Medeltidens bildvärld, Historiska museet, Stockholm, http://medeltid bild.historiska.se/medeltidbild/visa/foto.asp?imageId=9417105.

109 Söderberg, De gotländska passionsmålningarna, 334-44. See also English summary in Hernfjell, Medeltida kyrkmålningar i gamla Skara stift, 220. 


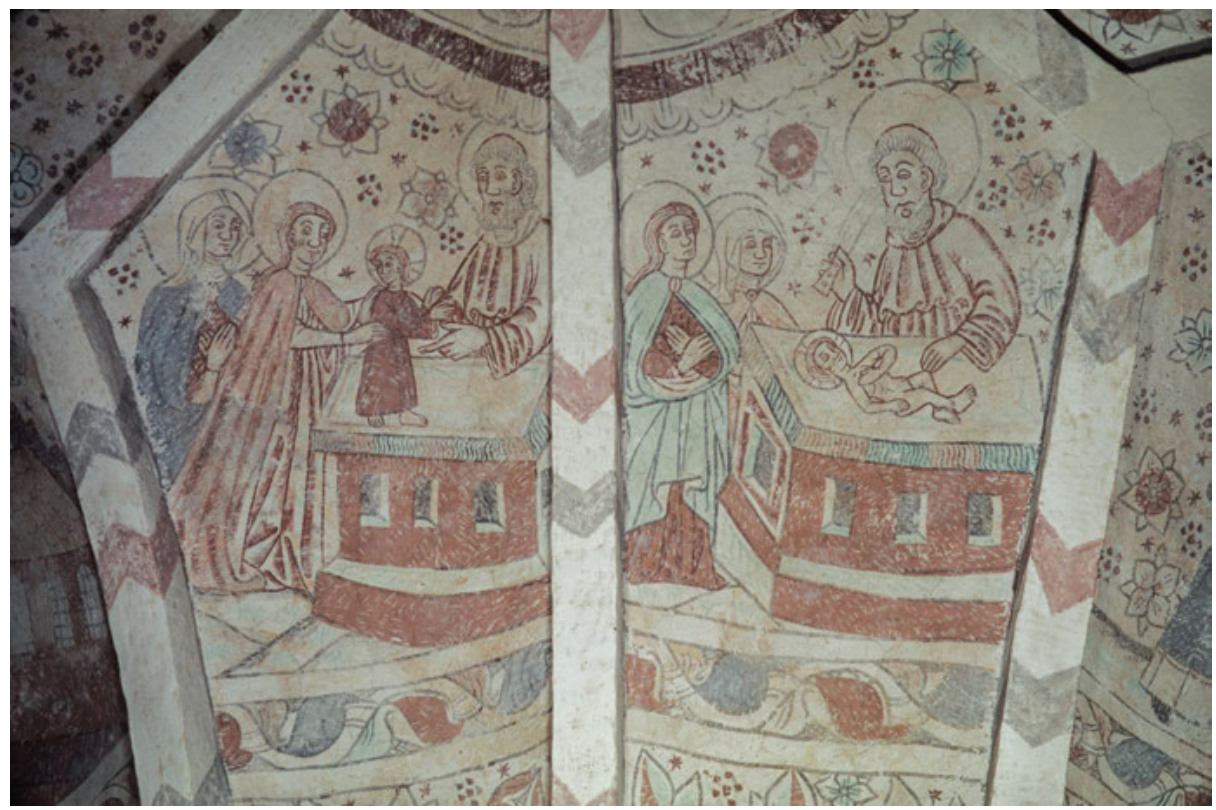

Fig. 17.9: Presentation in the Temple, c.1450-1475. Norra Strö Church, Scania.

specified is sometimes green, thus, the element of the red robe, or a particular robe for this ritual, may possibly reflect contemporary ritual practices. ${ }^{110}$

The murals of the vaults of Norra Strö are dated to $c .1450-1475$, and are assigned to the Scanian Vittskövle-group (Figs. 14.0 and 17.9). ${ }^{111}$ The Purification of Mary is narrated across three sections of the vault, followed by the Presentation and the Circumcision. The Purification of Mary shows a smallish, un-veiled woman, who holds a burning candle. She is accompanied by two veiled women, one of which holds an open basket with three birds. All three women are nimbed. The three women are followed by a procession of another thirteen veiled women (Fig. 14.0). A tonsured, bearded and nimbed "priest" receives the woman and her procession at the door of his stepped-gabled church. He holds a book in one hand, but with the

110 Nye Danske Magazin, indeholdende Allehaande Smaa-Stykker og Anmerkninger til Historiens og Sporgets Oplysning (Copenhagen: B. Brünich, 1806), 273. For post Reformation pratices in Sweden, see Gustavsson, Kyrktagningsseden i Sverige, 124.

111 One of the murals associated with the group is in Ysane, and is signed "Nils Håkansson," "1459." More hands are traceable within the workshop; however, the date is a welcome point of reference. The most recent summary on the Scanian churches is found Ann-Marie Nilsson, "Det medeltida kyrkorummets utsmyckning och utrustning," in Skåne. Landskapets kyrkor, ed. Markus Dahlberg and Ingrid Sjöström, Forskningsprojektet Sockenkyrkorna. Kulturarv och bebyggelsehistoria (Stockholm: Riksantikvarieämbetet, 2015), 138-64. 
other, he takes the woman's hand to lead her into the sacred space. There are no Joseph and no Christ Child present. In front of the door, behind the priest, we see the priest's attendant, who holds the censer in one hand, and the blessed water in the other. The next scene depicts the Presentation in the temple (Fig. 17.9). Here we see the accompanying woman without attribute from the Purification scene, Mary, Simeon and Christ; all nimbed. Simeon is tonsured and wears a cloak, rather like the priest in the previous scene. A central element in this composition is the altar upon which Christ stands, echoed in the following scene of the Circumcision.

The Purification scene of Norra Strö has also been described as "Mary's Churching." "The many accompanying women presumably reflects the high status of the woman who is to be introduced, and the town law of Gotland drawing the line at 24 accompanying women should here be remembered. In these images, Mary is in a sense miming the contemporary ritual situation. ${ }^{113}$ In Kumlaby, Södra Råda and Norra Strö, the imagery shows an interest in its own time and place, placing, or displacing, the biblical characters and the religious setting to medieval and local reality. ${ }^{114}$ This perception is even extended to the physical realm. The events appear to take place both outside and within the medieval parish church. The ambiguity seen in Södra Råda is even more apparent in Norra Strö. The door may be that of the temple, dressed as a medieval church, or it may be that of the medieval church dressed as the temple. It is simply hard to tell, as the whole scene takes place in a world that is both solid and elusive. The figures walk on the ground and the sacred building is there, but at the same time, they are surrounded by patterns of stars and flowers. There is a temporal ambiguity in these images that appears puzzling to the modern spectator, but that seemingly was quite unproblematic from a medieval perspective, for the imagery, like the rituals, bridged the "floating gap." This should probably not be perceived as a visual strategy, but rather as a cultural mode.

The Purification of Norra Strö with its long procession may also reflect other contemporary ritual situations. Liturgical plays composed for the feasts of the Virgin had by the later Middle Ages become increasingly popular. ${ }^{115}$ The standard themes of the Presentation-Purification plays were the fulfilment of God's promise to Simeon, and the offering of the first-born child according to the Law of Moses. ${ }^{116}$

112 Nilsson, "Det medeltida kyrkorummets utsmyckning och utrustning," 142.

113 A parallel to this phenomenon is found in late medieval expulsion iconography. For this, see Margarete Syrstad Andås, "Art and Ritual in the Liminal Zone," in The Medieval Cathedral of Trondheim. Architectural and Ritual Constructions in their European Context, ed. Margarete Syrstad Andås, et al., Ritus et Artes (Brepols: Turnhout, 2007), 119.

114 Lindgren, "Kalkmålningarna," 379-81; Knud Banning, A Catalogue of Wall Paintings in the Churches of Medieval Denmark 1100-1600, 4 vol. I-IV (Copenhagen: Akademisk forlag, 1966-1982), III: 8; IV: 62.

115 Lynette R. Muir, The Biblical Drama of Medieval Europe (Cambridge: Cambridge University Press, 1995), 19.

116 Muir, The Biblical Drama of Medieval Europe, 108-09, 230 ns 49-51. 
The Candlemas antiphon Nunc dimittis, "Lord let thy servant depart" (Luke 2: 29-32), also found in the ordinals of Nidaros and Linköping, was often included, whether it was sung or merely read out loud, in Latin or in the vernacular. Only rarely did the playwright present the audience with additions to the biblical narrative, but in the Digby Candlemes, a chorus of temple virgins dance at the beginning and at the end. ${ }^{117}$ The temple virgins hold candles and are assembled by Anna the prophetess for a procession to worship the child. This takes place to the sound of Nunc dimittis, and is followed by Simeon explaining the symbolism of the candles: The wax is Christ's humanity, the wick is his soul, and the flame signify his Godhead. A play from Paris also includes this element, but here the candle signifies the Holy Trinity. In the Eger play, Mary gives a candle as part of the offering for the Child, whereas in the Chester play, and in the Cangé Nativity play, the candles are there as a symbol of Mary's own purity. ${ }^{118}$ In the play tradition, Anna the prophetess and Anna the mother often figure, as do other family members. ${ }^{119}$ The two nimbed women included in the same picture frame as Mary in Norra Strö may thus possibly be the two Annas, and the procession may be inspired by temple virgins.

In addition to the Presentation storyworld core group, the Valö retable imported from Antwerp in the 1520s shows five men and four women (Fig. 17.10). An elderly looking Joseph carrying the cage with the birds is placed to the far left in the scene, flanking Mary. As the anti-theses of the old Joseph and his humble offering, a beautiful young shepherd boy stands to the far right flanking Simeon, holding a lamb. The lamb finds no explanation in the narrative from Luke, but might do so in Lev 12:1-8, as quoted above. This motif figures in sermons, as in the Norwegian Homily book, where it is explained that the Law demanded that a lamb and a bird should be offered to temple. ${ }^{120}$ However, also this picture convention finds its counterpart in medieval drama. The play of The Presentation from Florence begins with a series of prophets appearing to Simeon to tell him of the arrival of the Messiah. Then the shepherds return, to bring better gifts, including doves and food. The presence of additional men is a common feature in these late Gothic retables, whether they were imported from the north of Germany and the Low countries, or produced locally. The men might be biblical characters like prophets, although such a theory cannot be further substantiated, but it should also be considered

117 Muir, The Biblical Drama of Medieval Europe, 108-9.

118 Muir, The Biblical Drama of Medieval Europe, 108-9, 230 n.50. Some of the late medieval plays on the Presentation of Mary in the temple, a story belonging to her infancy cycle, feature Mary holding a candle followed by a procession of women. The women are temple virgins. These also appear in the visual arts, but there they mostly await Mary in the temple, while Mary arriving, is accompanied by her parents, Anna and Joachim.

119 Muir, The Biblical Drama of Medieval Europe, 109. Muir for instance mentions that the abovementioned Paris play includes Anna the mother.

120 Gamal norsk homilebok, 66-7. 


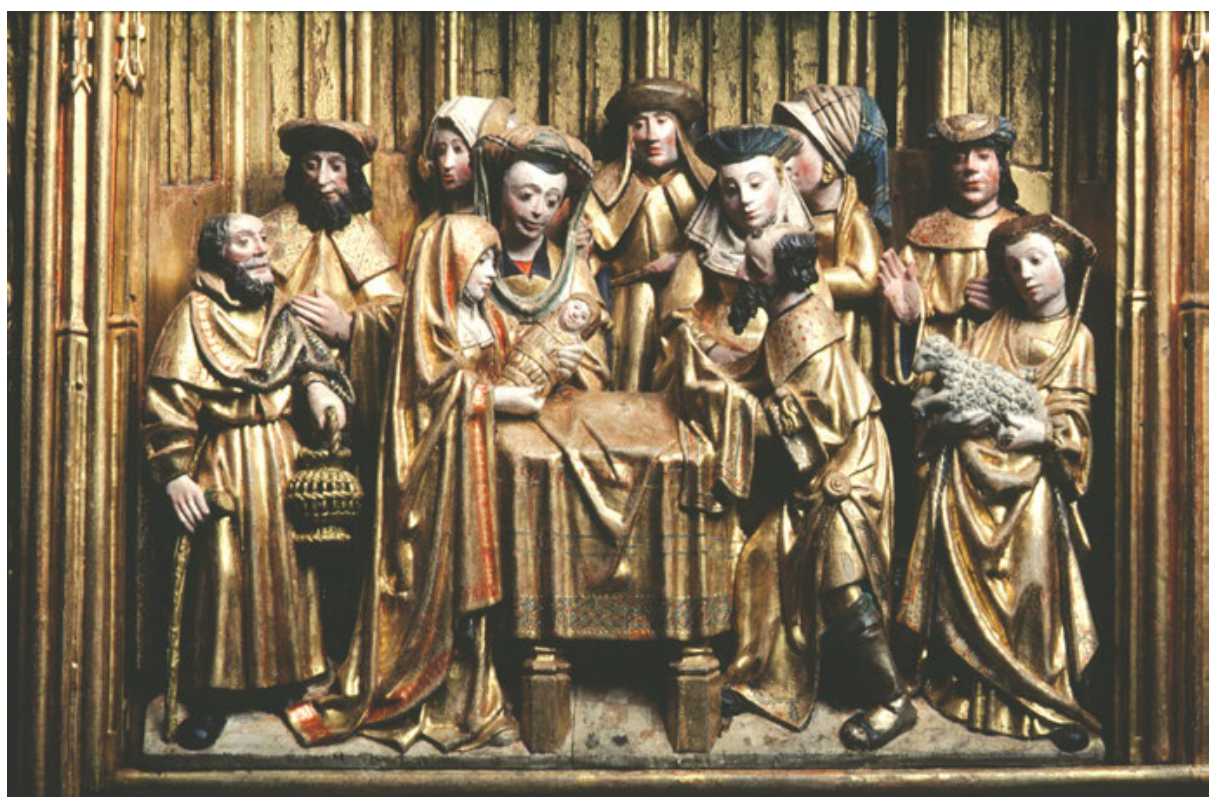

Fig. 17.10: Presentation in the Temple. Detail of retable, ca 1520, in Valö Church, Uppland.

that the extended holy family was in itself popular in this period, and they may therefore also be the ancestors and relatives of Mary. To the medieval audience, it might have been obvious that other family members should also be present on such an occasion. ${ }^{121}$

If these elements reflect the influence of medieval performativity on the visual arts, they may have made their way into the iconographic convention further south, but it may also reflect the local situation. Leif Søndergaard has studied the performative activities of some of the late medieval Danish guilds. ${ }^{122}$ Søndergaard looks particularly at the period of Lent and Pentecost, as well as the Corpus Christi feast, where strictly religious plays of saints' lives were combined with other plays and comedy, as well as religious processions. It was for instance the duty of the black smiths at Roskilde, the barbers at Flensburg, and the tailors of Odense and

121 David Cressy, "Purification, Thanksgiving and the Churching of Women in Post-Reformation England," Past and Present Society 141 (1993): 106-46; Natalie Knödel, "Reconsidering an Obsolete Rite: The Churching of Women and Feminist Liturgical Theology," Feminist Theology 5, no. 14 (1997): 123; McMurray Gibson, "Blessing from Sun and," 139-54.

122 Leif Søndergaard, "Kulturelle aktiviteter i gilder og lav," in Gilder lav og broderskaber i middelalderens Danmark, ed. Leif Bisgaard and Leif Søndergaard, Studies in History and Social Sciences (Odense: Syddansk Universitetsforlag, 2002). I am grateful to Line M. Bonde for bringing Søndergaard's study to my attention. 
Copenhagen, to hold processions at the feasts of Corpus Christi and Holy Trinity, carrying the lit guild-candle through towns and cemeteries. With the liturgical Candlemas procession fresh in mind, the "intertextual" aspect of medieval rituals is obvious. The Rosenkrans guild's legislations from Schleswig (1484) even prescribe processions around the guild hall on all the Marian feasts, in some cases it is specified that both men and women are to attend. A baldachin of green silk is then to be carried around (possibly to protect a Marian sculpture). This reference to the green silk recalls the green robe used at Churching, as mentioned above. The cases mentioned by Søndergaard offer a glimpse of a performative context that is otherwise rare in Scandinavia. Looking across the North Sea to Aberdeen, it was the obligation of the craft guilds to contribute to the Candlemas procession in 1442 and to the play on the same day. ${ }^{123}$ A generation later, the York mystery cycle stages Jerusalem more than once, putting on both scenes from the infancy of Christ, and Holy Week. We may not know much about the performative tasks the guilds in Scandinavian towns, but it is certainly likely that Jerusalem also through performance was brought into the townscapes of the episcopal sites, just like it was further south. The significant changes witnessed in the late medieval iconography of the Presentation may thus reflect a variety of contemporary ritual situations.

\section{Conclusion}

The ritual celebrations discussed above allowed medieval women to engage with the biblical narrative and the over-time added layers of pseudo-narrative that existed in the Christian storyworld centred on Jerusalem. Through the movements of the participants who entered their temple, Jerusalem was commemorated and made present in the smallest and most remote of churches. The preserved ritual texts and the imagery from medieval Scandinavia give us a peek into this storyworld. Mary is the key character, the pious and humble woman; an ideal for ordinary women to follow, and a role to be cast in. She came to honour the law and she lived without sin. These elements came to be linked to women's entry in their local temple.

As opposed to the biblical story, Candlemas and Churching were located in real time. Within this ritual framework, generations of women made new, but interconnected, memories; within this framework pseudo-genealogies were created and social connections made. Late medieval imagery however demonstrates how the model also worked the other way round. In the imagery discussed above, Mary is accompanied by a fluent group of people who might be everyone from Anna the prophetess, or Anna the mother, to her midwife, or other women and men of her

123 Muir, The Biblical Drama of Medieval Europe, 37. Play 19. At the end of "The Purification" the text is dated to 1468 . 


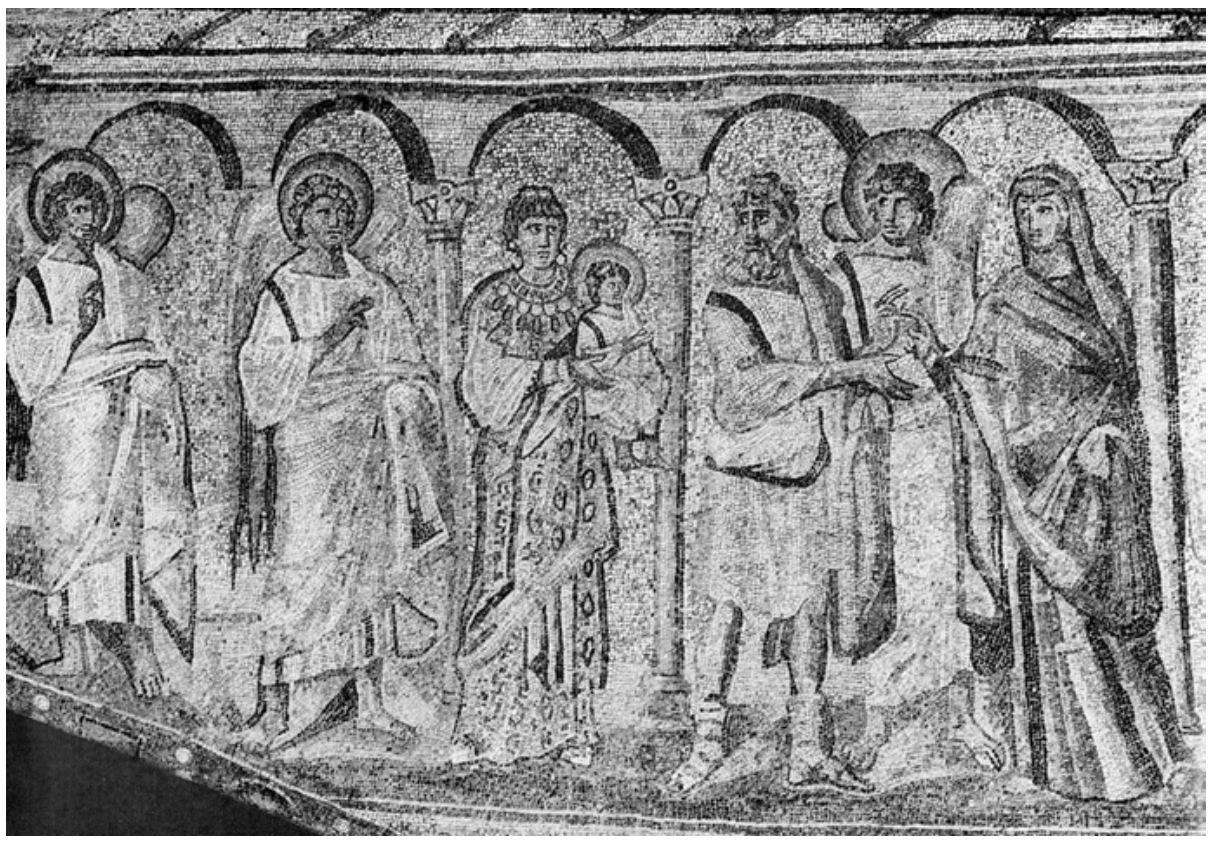

Fig. 17.11: Presentation in the Temple. Early fifth-century mosaic in S. Maria Maggiore, Rome. After I mosaici della patriacale basilica di Santa Maria Maggiore in Roma, 1967.

family. These images tell us little of the Purification of Mary, but quite a lot about medieval life and religiosity. A part from Joseph, Simeon, and Anna, some of these additional characters may of course have been identifiable from legends and liturgical plays, and they may thus have been "members of the remote past," still, medieval textual sources indicate that these visual conventions also mirrors late medieval ritual reality. The depiction of Mary's Purification was altered, remodelled, and created in the image of the medieval woman: Mary would not have come alone, nor would she have been followed by a procession of poor women, she would have been accompanied by the best and the finest of women. Anything else would simply be unthinkable. And the threshold of the Temple was the threshold of the parish church, for this was the locus where every family stored their stack of memories of their own, their aunts,' their cousins' and their neighbours' churching.

At the end of this survey, it is time to return once again to the vision of St Birgitta. She would have interpreted her revelation through the filter of her own experiences; through her own memories. Notwithstanding, she would also have seen two rather different visual representations of the Entry in the temple within the space of Santa Maria Maggiore in Rome, both offering a glimpse of the wider 


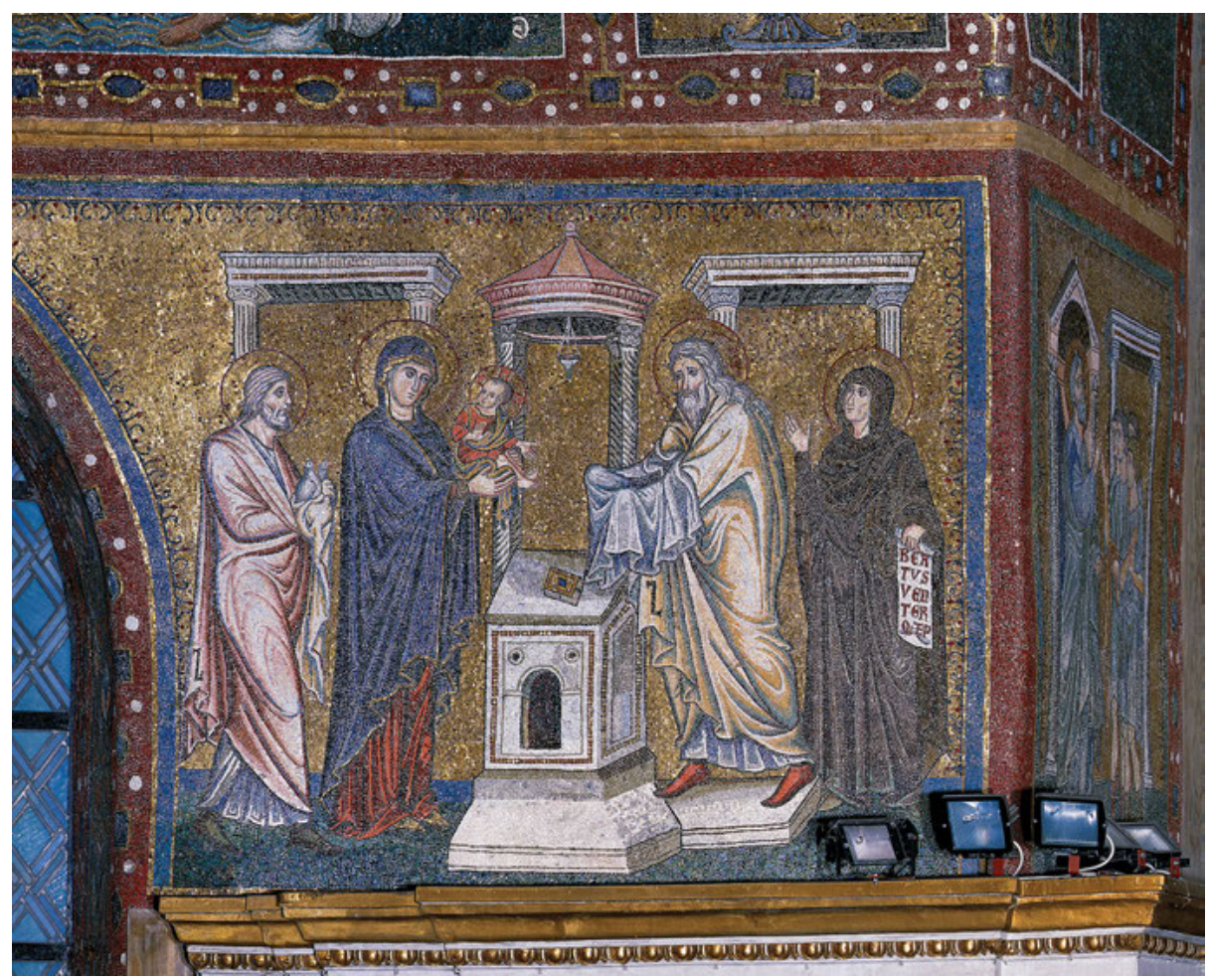

Fig. 17.12: Jacopo Torriti, Presentation in the Temple, 1296. Apse mosaic in S. Maria Maggiore, Rome.

context and perspective of this motif. ${ }^{124}$ The triumphal arch features what is generally considered the oldest known depiction of the Presentation in the Temple, dated to the reign of Pope Sixtus III (432-440) (Fig. 17.11). ${ }^{125}$ The mosaic shows the actual Meeting taking place outside the temple, and includes Virgin and Child, Simeon and Anna, angels, and a multitude of men, very possibly the "countless multitude of angels and the various ranks of God's saints," mentioned in St Birgitta's vision. ${ }^{126}$

In the same church we also find an apse mosaic by Torriti completed in 1296, where the motif is organized around the altar (Fig. 17.12). The scene appears to simultaneously take place both outside and inside, just like in the Scandinavian material. In depictions of the Presentation from the North, the main feature to indicate the temple is almost without exception the altar; creating a link

124 I am grateful to Lasse Hodne for discussing the mosaics of Santa Maria Maggiore with me.

125 Shorr, “The Iconographic Development of the Presentation in the Temple," 19.

126 These are also interpreted as Joseph and Anna. A figure with covered hands, who leaps forwards towards them, has been interpreted both as St. Peter and Simeon, for references to this debate, see Hodne, “The Turtledove,” 160, 65 n.3. 
between the temple of Jerusalem and the temple of the parish church, in which these representations are found. In a sense, it is just as much a depiction of the altar on the floor below the mosaic, behind the altar panel, or near the font, where Mass was celebrated every day, and where the offering made was that of the Eucharist. In may depictions of the Presentation, the Christ child stands upon the altar, or is held out above it as if enthroned, reminding the worshiper of His presence.

The significance of the construction of likeness should not be underestimated. In creating likeness between the mythical past and the reality of the present, time is in a sense eliminated. To explain medieval liturgy, Margot Fassler points to the importance of concepts of time. ${ }^{127}$ Time is both events and eternity. As said in the Lund text for the blessing of the candles on Candlemas; God is both before time and within time. ${ }^{128}$ This is part of the great mystery. The Liturgy serves a means to narrate history, and events carry meaning as distinct episodes in time. Liturgy of course depends upon time, and is impossible outside of time, but it also aims to transcend time. Fassler writes about repetition as both memory and sacrament. Her focus is on the repetition of music and sound, but the physical movements of the worshipers are equally relevant. ${ }^{129}$ Alf Härdelin has voiced similar ideas. He argues that a procession like the Candlemas procession should be understood as sacramental. ${ }^{130}$ What takes place is not merely re-enactment. The physical acts, the entry in the Temple (church) with the Messiah (candle) constructs presence - and presence eliminates time. For the individual soul, the procession mimes a spiritual likeness, thus making his performance a preparation for the final processional entry into the heavenly Jerusalem.

127 Margot E. Fassler, "The Liturgical Framework of Time and the Representation of History," in Representing History, 900-1300: Art, Music, History, ed. Robert Maxwell (University Park PA: Penn State University Press, 2010), 150-3.

128 Härdelin, Världen som yta och fönster, 288-9.

129 On the significance of repetition, see Chapter 15 (Line M. Bonde), 310-7.

130 Härdelin, Världen som yta och fönster, 156. 